Est Ag 35 (2000) 291-356

\title{
Un catecismo para esclavos
}

Cuando llegó a mis manos, hace unos años, el catecismo que centra el presente trabajo, tuve ocasión de comentarlo con una persona conocida. Su extrañeza se reflejó en una negativa a convenir que fuera bueno un catecismo específico para esclavos, porque -ese era su razonamiento- había que presentar la misma doctrina a todos, sin excepciones ni tratos de favor. Yo le hice caer en la cuenta de que, de la misma manera que había adaptaciones para niños o para personas de escaso nivel de formación, había quien se había decidido a tomar la pluma para llevar a cabo una adaptación que consideraba útil para presentar la fe a los negros esclavizados. No se trataba, por tanto, de preferencia excluyente, sino de adaptación necesaria.

Lo que ocurre es que la lectura, y consiguiente estudio, de este catecismo, implica en este caso una situación especialísima, con arreglo a la cual es preciso limar las expresiones, porque todo el contenido de la obra que voy a comentar está transido de dolor y sufrimiento. Me resulta imposible tomar a la ligera cualquier expresión, por mínima que sea, al encajar la obra en el ambiente que la vio nacer, y poder comprobar la ingente acumulación de sufrimiento, ordinariamente reducido a un silencio opresor, acumulado sobre las espaldas y sobre las mentes de los negros reducidos a esclavitud.

Ellos son los destinatarios de este catecismo. Pero sus existencias estaban amasadas con las lágrimas y la sangre de una postración a la que se habían visto arrastrados, y de la que resultaba imposible evadirse. Vergüenza para el género humano, pero practicada desde la más remota antigüedad, y que aún no ha sido desterrada de las formas de explotación de unos hombres hacia otros semejantes suyos, a pesar de todas las declaraciones solemnes y oficiales. Me resulta imposible olvidar el cuadro entrevisto de sufrimientos que este texto de catecismo muestra entre líneas; y aunque haya que hablar del autor y de sus pensamientos catequéticos, éstos no pueden desvincularse de la inhumana vejación a la que estaban sometidos los negros a los que el autor del catecismo intenta presentar la fe cristiana. Es, por tanto, una rareza entre los 
catecismos conocidos, tanto por los destinatarios directos, como por la cruel situación que aflora desde cada una de sus líneas.

Conozco el catecismo desde la edición titulada Doctrina para negros, a cargo de Javier Laviña1. Éste se hace responsable de la transcripción del texto manuscrito, así como de la introducción que lo acompaña. No trato de desviarme del tema, si en un primer momento centro la atención en la edición referida y sus notas.

Laviña hace una referencia incompleta al manuscrito que reproduce, desde el momento en que señala su localización en la Biblioteca Nacional "José Martí", de La Habana, sin ofrecer signatura de la obra². Cuando más adelante indica la existencia de varias ediciones, precisa únicamente que el original se encuentra en la sección de manuscritos de dicha Biblioteca ${ }^{3}$. Las ediciones que reseña del catecismo estudiado son:

$$
\begin{aligned}
& 1^{\text {a }} \text { ed., La Habana, } 1797 \\
& 2^{\text {a }} \text { ed., La Habana, 1818, (¿impresa?) } \\
& 3^{\text {a }} \text { ed., La Habana, Boloña, } 1823 \text { (impresa). }
\end{aligned}
$$

Las dos primeras ediciones son conocidas sólo por referencias. Pero Laviña no deja claro si cuando habla de la primera edición se está refiriendo al original manuscrito, datado, por tanto, en 1797, o si se refiere a una edición impresa, en cuyo caso el manuscrito es cronológicamente anterior, aunque no se sepa en cuántos años. En caso de que las tres ediciones aludidas hayan sido impresas, aunque no se conozcan todos los datos de cada una, serían cuatro las ediciones, si a ellas se añade la versión manuscrita reproducida.

Laviña divide su estudio previo en tres partes bien diferenciadas: $1^{\mathrm{a}}$ parte, Introducción, con un análisis riguroso de los aspectos económicos que formaban la trama de la explotación del azúcar, y que dio ocasión a una esclavitud, que no se había interrumpido desde muchos años atrás, pero que se incrementó con vistas a la rentabilidad acelerada del cultivo de la caña de azúcar. $2^{\mathrm{a}}$ parte, Esclavitud y vida cotidiana, parte bien cuidada y expuesta. Y $3^{\mathrm{a}}$ parte, Iglesia y esclavitud. Esta parte tercera adolece, a mi entender, de serios defectos. El no ser entendido en economía me impide verlos, si los hubiera, en la parte primera; la parte segunda, centrada en la vida diaria de los esclavos, me

1. J. Laviña, Doctrina para negros, Hospitalet de Llobregat, Sendai, 1989.

2. Pg. 11.

3. Pg. 123. 
parece perfecta, y nada tengo que observar. Pero mi condición de entendido en catecismos, y un tanto también en la vida de la Iglesia, me lleva a percibir numerosos e importantes fallos que Javier Laviña ha despachado con una visión superficial. Más aún, me parece que resulta imprescindible señalar la fuerte oposición que se encuentra entre esta parte $3^{\mathrm{a}}$, en conjunto respetuosa con las formas, y algunas afirmaciones que aparecen en el epílogo del libro. Podría dar la impresión de que introducción y epílogo están redactados en momentos distantes, y que una y otro no tuvieran nada que ver entre sí; lo que aparece cuidada y respetuosamente en la parte $3^{\text {a }}$ de la introducción se desbarata con las afirmaciones del epílogo.

\section{ANÁLISIS DE LA APORTACIÓN DE JAVIER LAVIÑA}

El primer requisito es consignar el nombre del autor del catecismo redactado para la evangelización de los esclavos negros: Antonio Nicolás Duque de Estrada, del que diré una palabra más adelante. Pero resulta significativo que Laviña no se pare con un poco de calma a decir una palabra sobre el autor del escrito que presenta. Hace referencia de pasada a algunos rasgos que se desprenden de la obra ${ }^{4}$, pero son claramente insuficientes.

Para examinar con algo de detenimiento el distinto tono que existe entre la introducción y el epílogo de Laviña, y no dejarlo en afirmación gratuita por mi parte, es de justicia reconocer que Laviña recoge en ocasiones el pensamiento directo de Duque, al que cita, en la parte $3^{\mathrm{a}}$ de la introducción. Según esto, Duque recuerda que la cristianización es obligación de los amos; reclama que se hagan esfuerzos para que los negros entiendan la doctrina cristiana, sin conformarse con una repetición mecánica; Duque se manifiesta en contra de la idea de incapacidad absoluta por parte de los negros, y señala la grave dificultad de la deficiente comprensión del idioma castellano; Duque aconseja la enseñanza progresiva y continua; y también recomienda la utilización de ejemplos y comparaciones comprensibles para los negros. Todo esto queda reflejado por Laviña en la página 50 de la introducción. A la vista de esto, no se entienden demasiado bien las afirmaciones que Laviña firma en la página 125 (ya en el epílogo) donde habla del "escaso interés que tenían los capellanes en la evangelización"; también asegura que estos capellanes "veían en el africano una fuente de vicios", o consideraban "casi imposible que lle- 
garan a la comprensión mínima de la religión". Aun resulta Laviña más explícito -y más contradictorio- al dejar de hablar colectivamente de los capellanes y pasar a hablar individualmente del autor del catecismo, Antonio Nicolás Duque. Laviña asegura que "apunta Duque [que] tenía dudas sobre la condición humana del negro". Igualmente, Laviña afirma que "en ningún momento duda [Duque] de la necesidad de mantener el orden en la plantación". Me parece percibir una tendencia a trivializar el papel del capellán de las plantaciones, con una lectura sesgada.

Por eso mismo, procede analizar algunos temas con mayor detenimiento.

\section{CUESTIONES RELATIVAS A LA INTRODUCCIÓN DE LA OBRA}

1. Obligación de los amos. Laviña recoge la noticia de la publicación de la Real cédula de 31 de mayo de 1789, según la cual los amos tenían que instruir a los esclavos; esta disposición provocó la reacción de los propietarios, que no deseaban que alguien se inmiscuyera en sus asuntos con el pretexto de vigilar el cumplimiento de lo ordenado; los propietarios justificaban en su descargo que ya tenían encomendada la explicación a los esclavos viejos (que no eran productivos) y que era suficiente con esto y con la recitación de la doctrina y el rezo del rosario. Es patente que esto conducía a una deficiente cristianización, superficial y rutinaria, contra la cual se manifiesta expresamente Antonio Nicolás Duque: «Adviertan los amos, y adviértanlo bien, que no cumplen con la gravísima obligación que tienen de instruir a sus esclavos (y lo mismo es de los demás domésticos) con sólo que sepan hablar como cotorras»5.

Es inevitable hacer una salvedad, omitida por Laviña. Mientras los propietarios de plantaciones y de esclavos hacían referencia a la "obligación" impuesta por la Real Cédula citada, y manifiestan sus salvedades respecto al control sobre su cumplimiento, Antonio Nicolás Duque está hablando en otro registro: la "gravísima obligación" que tienen los amos ante Dios, obligación que les hace responsables ante Él de su cumplimiento, con o sin disposiciones legales al respecto.

2. Preocupación por la cristianización efectiva. Laviña se hace inicialmente eco de la preocupación de Duque por una cristianización genuina y válida

5. Pg. 73. Más adelante explicaré la complicación de utilizar un sistema adecuado de citas directas del texto de Nicolás Duque. 
de los esclavos; incluso recoge la indicación de Duque a otros capellanes, en el sentido de que insistan que la cristianización no es en beneficio del amo, sino en el del propio esclavo ${ }^{6}$. No resulta comprensible, por tanto, que Laviña fuerce las cosas hasta el extremo de tachar de "ingenuo" a Duque por el hecho de pretender que los doctrineros o capellanes tengan una mayor dedicación a los esclavos en forma directa7; o al afirmar "el escaso interés que tenían los capellanes en la evangelización"8. Ya ha aparecido el interés de Duque porque no repitan «como cotorras» una doctrina no entendida; apárecerá más adelante su deseo de una explicación adecuada. El interés directo, la dedicación personal de los capellanes a la labor de educar adecuadamente a los esclavos negros no puede ser interpretada precisamente como falta e interés. Cabe una lectura, que es la que Laviña prefiere: que cuando Antonio Nicolás Duque está aconsejando esa personal implicación de los religiosos es porque ésta no se efectuaba en modo alguno. Pero cabe también otra lectura, tan válida como la anterior: que Duque reclama la intensificación y mejora de lo que ya se está haciendo.

Acaso Laviña hubiera deseado encontrar entre lo escrito por Antonio Nicolás Duque algo parecido a «no se tomen los capellanes demasiado interés en cómo se lleva a cabo la enseñanza de la doctrina cristiana, ni se preocupen por si la entienden o no». Algo parecido a esto justificaría hablar de poco interés en la evangelización. Pero nada semejante se encuentra, y no es posible acusar a Duque de falta de preocupación por una evangelización adecuada. Si Laviña llega a tal conclusión, es labor suya mostrar en qué se apoya. De otro modo, su deducción está en precario.

3. Lamento por la obtención de escasos resultados. Laviña afirma, con un no disimulado aire de satisfacción, que "el esclavo, ante la perspectiva que se le ofrecía en el ingenio, optaba por: o bien se resistía a los mensajes que le pudiesen enviar y escapaba -esta situación fue muy frecuente entre los negros bozales ${ }^{9}$, o aceptaba, de forma aparente, la religión de tal manera que pudiera sobrevivir sin graves conflictos"10; aduce, además, el sincretismo religioso

6. Pg. 48 y 51. Duque.

7. Pg. 124. Más adelante volveré sobre la nota de "ingenuidad" que Laviña asigna a

8. Pg. 125.

9. Bozal: "Dícese del negro recién sacado de su país".

10, Pg. 125. 
de los grupos afroamericanos de Cuba. Su razón es cierta en parte, ya que las duras condiciones de la esclavitud obligaban a cualquiera a sobrevivir al precio que fuese, y a tener que aceptar, de grado o por fuerza, múltiples imposiciones tanto en el orden religioso como en otros terrenos. Pero precisamente esta religión impuesta y coercitiva es la que no acepta Duque, partidario de una religión explicada, entendida y aceptada. Esto no resulta siempre sencillo en condiciones de libertad, por parte de la persona a la que se le presenta; pero resulta aún mucho más difícil en condiciones de esclavitud, donde no había margen para la elección ni en el terreno religioso, ni en el económico, ni en el familiar, ni en otro alguno.

Si la presentación de la religión cristiana, no disponía del margen de elección personal y de aceptación libre que hoy se exige, resulta inadecuado esperar que tal margen de libertad se concediera hace dos siglos, cuando no era lugar común del pensamiento, y menos aún a unas personas esclavizadas. Pero no se puede dejar sin mencionar otra causa, importantísima, del fracaso en la cristianización de los esclavos, que no gravita en la libre aceptación religiosa. Duque apunta a otra causa, que también Laviña anota (aunque parece no concederle demasiada importancia): la escasa o nula comprensión del idioma por parte de los esclavos. Una religión que no se comprende, o se comprende sólo parcial o superficialmente, porque el conocimiento de la lengua en que se presenta es también parcial o superficial, difícilmente puede producir los resultados apetecidos. Todos los esfuerzos realizados por acercar los principios religiosos a unas personas (en este caso esclavos) que no comprendían la lengua, tropiezan con una traba tan radical que inutiliza la mayor parte del interés puesto en explicarlos.

Me sorprende francamente que Laviña no recale más en esta dificultad idiomática como una de las causas del escaso resultado del esfuerzo evangelizador. El propio Laviña se manifiesta muy bien documentado sobre esta cuestión del idioma como un medio (o, por mejor decir, un arma) utilizado por los amos contra los esclavos: "Los mecanismos para dividir a los esclavos eran variados: en primer lugar, los propietarios tomaban las precauciones necesarias para no comprar un elevado número de esclavos de la misma etnia, de forma que entre los esclavos de una plantación fuese, si no imposible, al menos muy difícil la comunicación"11. En estas condiciones, con negros de diversas procedencias y de diversas lenguas, con graves dificultades para entenderse entre sí, y tantas o más para adquirir conocimientos del castellano, resultaba muy complicado hacer una presentación válida de la fe cristia-

11. Pg. 31 
na; y resultaba dificultoso llegar a entenderla con garantías mínimas. No se puede siquiera comparar la situación de los negros esclavizados con la situación de los indios de América Central o del Sur, cuando, pese a los brutales sometimientos político-militares, los misioneros realizaron el ingente esfuerzo de presentarles la fe cristiana en sus respectivas lenguas; aun contando con todas las dificultades inherentes, la comprensión de la misma podía ser mucho mayor, y la aceptación podía ser también más válida. A pesar de ello hubo mucho de conversiones aparentes, por sometimiento a los conquistadores españoles o de otras nacionalidades. Pero en el caso de los esclavos negros, su situación es tan distinta en cuanto a la comprensión de lo que se les presentaba que no admite siquiera comparación.

En modo alguno pretendo desviar la atención hacia el problema de la dificultad de comprensión, para eludir la importancia de una religión impuesta y no aceptada. Entiendo que cada una de estas razones es lo suficientemente notable como para que la suma de ambas arroje como resultado una religión no entendida ni asumida. Los esfuerzos de los evangelizadores, como es el caso de Duque al componer su catecismo, deben ser comprendidos y valorados, aunque haya que reconocer la fortísima limitación a que se veían sometidos.

4. Equívoco entre la intención de los amos y la de los capellanes. Laviña demuestra un buen conocimiento de la situación de las plantaciones cuando afirma: "Duque Estrada es consciente de la situación de los esclavos en el ingenio, y del lugar que ocupa la religión dentro de la escala de valores de los amos (...) La religión se utilizó como un elemento de control indirecto de los esclavos porque intentaba inculcar deberes y sumisión a la voluntad de los amos y mayorales. Desde el punto de vista económico, era rentable la enseñanza de la religión mientras el período de amortización del esclavo era largo, pero cuando se aumentó la rentabilidad del negro en la plantación, y por tanto el tiempo de amortización era menor, la socialización del esclavo dejó de interesar a los propietarios"12.

La primera frase reproducida constata la diversa mentalidad del evangelizador Duque de Estrada, y la corrientemente imperante entre los amos. Tal mentalidad no tiene por qué ser coincidente. Cuando Laviña afirma que la religión se utilizó tal como describe, queda una pregunta en el aire: ¿fue utilizada así por parte de los amos interesados en mantener un determinado orden?, ¿fue utilizada así por los evangelizadores?, ¿o fue utilizada por

12. Pg. 124. 
ambos? Seguramente, con arreglo a los criterios de la época, imperantes en la metrópoli, los capellanes carecían de una sensibilidad social que no había aflorado suficientemente a finales del XVIII.

Resultaría tan ingenuo suponer una exquisita sensibilidad social en los capellanes, como imaginar que éstos fueran predicando la emancipación, la independencia, la rebelión o la lucha armada de los esclavos contra sus amos, en nombre de Dios y de la religión. Pero no se puede dejar de lado, como el mismo Laviña reconoce, que en un régimen de un aprovechamiento de las energías de los esclavos a largo plazo, los amos, no tenían demasiado inconveniente en destinar una parte de las mismas a la formación religiosa; pero las cosas cambiaron radicalmente cuando se trataba de aprovechar y explotar esas energías en el menor tiempo posible, aun consumiendo a la persona: entonces la religión, en la mentalidad de los amos, no fue considerada rentable, y resultaba una pérdida de tiempo (y de energías). Y es precisamente entonces cuando surge la obra de Duque de Estrada reclamando para la enseñanza de la religión el tiempo que tratan de negar los amos. De ahí que sea indispensable considerar que existió una clara diferencia entre la mentalidad de los amos y la de los evangelizadores; y tratar de identificar ambas es una torpeza, en el mejor de los casos.

5. Defectuosa utilización de la religión. Ya ha aparecido antes una forma de tergiversación de la genuina fe religiosa, como si su finalidad fuera la de contribuir a sostener un determinado sistema social. Hay que diferenciar con nitidez la realidad que desempeñó, de la finalidad que tenía en sí misma la religión. El que de hecho fuera así, y que el modelo económico-social buscara apoyos y legitimaciones en todo cuanto tuviera a su mano, también en lo religioso, puede resultar un hecho comprobable, máxime cuando el modelo de la explotación de la caña de azúcar constituyó la principal fuente de ingresos de la isla de Cuba, y cuando una potente oligarquía controlaba y dominaba este mercado, como una fuente de riqueza que no se cuestionó. A finales del XVIII, no se había despertado aún en Cuba el sentimiento nacionalista que prendió en otros países de Sudamérica ${ }^{13}$. De hecho, la religión y la estructura

13. Casi contemporáneo del texto de Antonio Nicolás Duque de Estrada, pero con un claro sentimiento nacionalista, alentado y adobado con una mezcla de razones religiosas y patrióticas, hay que situar el Catecismo o instrucción popular, de Juan Fernández de Sotomayor, Cartagena de Indias, 1814, que aboga por la independencia de Colombia de 
de la Iglesia (jerarquía, párrocos, clero, religiosos) pudo consentir un orden social establecido.

Pero esto es bien diferente que señalar que ésta es precisamente la finalidad de la religión. Laviña formula tres conclusiones, de evidente tono marxista, según las cuales, la finalidad de la religión estaba perfectamente trazada como sostenedora del orden establecido:

$1^{\mathrm{a}}$ "Es evidente que la primera y principal función que debía cubrir [la religión] era la adaptación del esclavo al sistema de plantación; de ahí el interés del capellán en establecer comparaciones entre Dios y el amo";

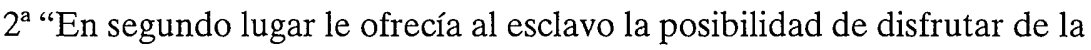
libertad en el más allá, pero siempre que cumpliese su función en el ingenio";

$3^{\text {a }}$ "En tercer lugar debía servir para frenar la actividad levantisca de los esclavos y evitar las huidas, sublevaciones y suicidios"14.

Es obligado responder a semejantes conclusiones. Es cierto, en primer lugar, que la religión, y las personas que la hacían patente y visible contribuían de hecho al sostenimiento de un orden social, que no se ponía en tela de juicio. Pocas o ninguna voces, desde dentro o desde fuera de la Iglesia, se alzaban para denunciar la esclavitud, y menos aún el enriquecimiento de unos sobre la base de la explotación de otros seres humanos privados de libertad. Pero Laviña comete una torpeza incuestionable al asegurar que ésta era "la primera y principal función que debía cubrir la religión”. El mal uso, o la legitimación pretendidamente religiosa de los defectos o de los intereses de unos hombres, so capa de pretextos religiosos, no impide ver claro que el abuso o el defecto no es la finalidad que la religión pretende.

En segundo lugar, resulta totalmente falso afirmar que la religión ofrecía al esclavo un horizonte de libertad en el más allá, del que carecía en su miserable vida presente, como si esa razón hubiera salido de las palabras de Antonio Nicolás Duque. Éste presenta, como era su obligación religiosa, la doctrina del cielo y del infierno, en términos que pudieran ser percibidos por los esclavos. Pero jamás se encuentra una sola línea expresa, o sobreentendi-

España, a impulsos del ejemplo suscitado por la Revolución Francesa, y, sobre todo, por la Guerra de la Independencia. Nada de esto se encuentra en el catecismo de Antonio Nicolás Duque.

14. Pg. 125. 
$\mathrm{da}$, en que hable de una vida futura que llevara a los esclavos a evanescer sus obligaciones, o a dulcificar sus sufrimientos, con una sublimación religiosa.

En tercer lugar, la presentación de una moral cristiana, no podía desconocer las penalidades sufridas por los esclavos en la plantación y su incremento cuando huían. La teoría del mal menor padecido y aceptado se impone frente a la posibilidad, no meramente ficticia, del previsible mal mayor en caso de fugas ${ }^{15}$. Duque no se propone como finalidad conservar el orden establecido, sino aliviar los crudos sufrimientos realmente padecidos por los esclavos, reduciéndolos al mínimo posible. Además, la doctrina de "lucha de clases" y de invitación a la rebelión no ha surgido de la entraña del mensaje cristiano, y, por tanto, es lógico que no se encuentre en las propuestas que redacta Duque. De la misma forma, la presentación de la moral cristiana no puede incitar al suicidio, como forma de escapar de una realidad, por cruda que resulte, máxime con la consideración peyorativa que tenía el poner fin a la propia vida, y sin haber podido incorporar, a finales del XVIII, las consideraciones que sobre el tema ha elaborado la moderna psicología.

Más aún, la palabra "librar" aparece en el catecismo de Duque en el contexto de "librar del infierno" (p. 84, 85) o su equivalente "sacar del infierno" (p. 105); y la palabra "huir" no es utilizada para hablar de las fugas o evasiones, sino para hablar de "huir (fuir) de la ocasión de pecado" (p. 101,112).

Laviña es reiterativo al insistir en la idea de que el capellán propiciaba la sumisión de los esclavos al sistema social establecido, precisamente por el empleo de una religión de sumisión, que hablara del premio del cielo al esclavo obediente ${ }^{16}$. Las dos razones en que Laviña se apoya resultan bastante endebles. Por un lado remite a la comparación establecida entre Dios y el amo. Es cierto que tal razón o comparación aparece en la páginas del escrito de Duque ${ }^{17}$; pero no es menos cierto -y Laviña lo silencia- que también aparecen las diferencias entre Dios y el amo ${ }^{18}$. Por otro lado, la segunda razón en

15. Antonio Nicolás Duque entiende y expresa perfectamente estos términos cuando habla de las relaciones que ha de tener el capellán con el mayoral, pues el primero ha de apadrinar a los esclavos «y no puede excusarse de hacerlo siempre que ellos se lo soliciten porque se hace cargo que es menos malo que se les disimule por entonces, que no que anden fugitivos, haciendo falta para el trabajo, expuestos a hacer perjuicios a otros, y a que los golpeen o sea necesario cogerlos con perros".

16. Pg. 52, 124, 125.

17. «Así también desde que nacemos, desde que nos parió nuestra madre somos esclavos de Dios, porque él es el amo de todo y tenemos obligación de servirle, como el esclavo a su amo: lo que Dios quiere que hagamos es que guardemos sus mandamientos, que no fagamos pecados. Esa es nuestra tarea» 
que Laviña se apoya es la de una supuesta descripción alambicada de un cielo entrevisto y magnífico para los esclavos buenos, es decir, para los esclavos sumisos. Y esto no es cierto. Duque hace una presentación del cielo, con una descripción no solamente espiritual, sino también material (descanso, supresión de enfermedades,...), pero tal visión está destinada tanto a los esclavos buenos (p. 89) como a los amos buenos (p. 114), a las mujeres buenas (p. 116), $\mathrm{y}$, en general, a los buenos cristianos:

«Los buenos christianos, que hacen lo que Dios manda, más que [=aunque] sean negros, esclavos, pobres, más que tengan llagas, calentura u otra enfermedad, van al cielo quando se mueren; los malos christianos os. $[i=0$ sea?]no hacen lo que manda Dios, aunque sean blancos, libres, ricos, caballeros, más que no tengan enfermedad alguna, van al infierno quando mueren, porque a los que son buenos se lo pagan Dios con el cielo; y a los que son malos los castiga al infierno. Y así el cielo como el infierno son eternos, duran para siempre, nunca se acaban»19.

Volveré más adelante sobre esto con más extensión.

6. Actitud del capellán. Duque afirma una y otra vez que el capellán ha de ser comprensivo con los esclavos. Y Laviña se hace eco de semejante propuesta $^{20}$; pero a la vez retuerce el argumento, porque lo sitúa entre una de las razones que sostenían y repetían el sistema social vigente: "En la concepción de Duque de Estrada, el doctrinero debía ser no sólo el profesional de la evangelización, sino el padre y consuelo de los esclavos, al margen de la actividad productiva, pero manteniendo y haciendo respetar la jerarquización del ingenio"21.

Me parece que se produce una burda manipulación de los motivos en que se basaba la actitud del capellán, porque, para Laviña, la actitud comprensiva hacia los esclavos no es más que un medio para mantener el orden. Sin decirlo, Laviña parece estar haciendo el paralelismo entre el "policía bueno" y el

18. «Pero miren ustedes cómo Dios no face como mayoral ni como amo, sino como Padre. Acá, quando el esclavo cumplió su tarea no lo castigan, pero tampoco le pagan nada (...) Pero Dios no face así: al que cumple su tarea, al que guarda sus mandamientos, no se calla Dios la boca, sino que le dice: ven acá, fulano: tú has cumplido con tu obligación, no como el mal esclavo, sino como el buen hijo; ven ahora al cielo para estar conmigo que soi tu Dios, y tu Señor, y tu Padre a descansar para siempre, para siempre».

19. Pg. 72.

20. Pg. 48.

21. Pg. 125. 
"policía malo" de los interrogatorios, asignando al capellán el primer papel y al mayoral el segundo, pero ambos, en definitiva, al servicio de la misma causa. Si esto fuera cierto, no sería una actitud sincera sino calculada.

$Y$ no es precisamente lo que se deduce de las palabras de Duque, quien intenta la presentación del cristianismo desde la acogida y la comprensión sincera y leal del capellán hacia los negros. Más aún, la recomendación de que se acerque a ellos ganando su confianza está ordenada a que la aceptación y aprendizaje de la doctrina cristiana que intenta presentarles discurra por esa misma vía, en lugar de hacerlo por el castigo y el látigo:

«Y para que ellos tomen la instrucción con gusto es necesario enseñarlos con esta paciencia, con esta dulzura, no con enojo y a golpes (como se fixa un clavo) con el azote en la mano, haciendo que el infeliz esclavo mire el rato dedicado a la instrucción como tiempo destinado a la mortificación, al tormento, y que tenga más cuidado con el látigo que con la doctrina»22.

Laviña destaca también el párrafo anterior, y afirma que, frente a la actitud de respeto y consideración hacia los esclavos, recomendada por Duque, "los capellanes de ingenio o los doctrineros usaban frecuentemente la violencia para enseñar la religión". Es cierto que cuando se hace una recomendación puede ser para evitar caer en el defecto que se señala; o también para corregir la práctica defectuosa. Podría entenderse, pues, a partir de la afirmación anterior, que había una transmisión religiosa a los esclavos basada en el látigo. No es posible, sin embargo, conocer si era abuso generalizado $u$ ocasional23. De esta manera, incluso la recomendación de actitud comprensiva y respetuosa hacia los esclavos puede ser puesta en tela de juicio, y puede ser vista como un forma sutil de control, cuando lo que se deduce de la palabras de Duque es irreprochable, incluso contando con la actuación defectuosa que otros evangelizadores pudieran llevar a cabo.

7. Independencia económica del capellán. La situación económica del capellán ha de enmarcarse, para ser entendida, en la situación de la progresiva autonomía de las plantaciones, tanto en lo económico, como en lo que se refiere a la dependencia de la parroquia. La concepción jurídica de la parro-

22. Pg. 75.

23. A continuación, (pg. 49), Laviña muestra la preocupación generalizada por el incremento de suicidios entre la población esclavizada, en el momento del auge de la explotación, lo que llevó a la toma de conciencia por parte de autoridades religiosas y civiles para conseguir evitarlos; sin embargo, se quitó importancia al asunto, cediendo la alarma inicial que había suscitado. 
quia estaba vinculada, desde tiempo atrás, a un determinado territorio; éste es relativamente limitado en el caso de los núcleos urbanos, pero resulta muy extenso en el agro. En el caso cubano, las plantaciones se hallaban diseminadas en un territorio extenso, como explotaciones agrícolas, al fin y al cabo. La asistencia a los actos de culto no siempre resultaba posible por la distancia, y los hacendados prefirieron la construcción de capillas dentro de la plantación, atendidas por un capellán contratado a su servicio. Otro conflicto con las parroquias lo constituyó la tributación de los diezmos, y de no menor entidad fue el problema del traslado de cadáveres para ser enterrados en los cementerios parroquiales, conforme a derecho, lo que enfrentó a los propietarios y a los eclesiásticos. Laviña describe acertadamente estos problemas y las razones que se barajaron por uno y otro lado en cada cuestión ${ }^{24}$. El resultado final fue que la distancia física del centro parroquial derivó en autonomía y progresiva independencia de las plantaciones con relación a las parroquias (e indirectamente al obispado) como consecuencia de un autoabastecimiento de servicios religiosos suministrados por el capellán. Éste, de raza blanca, y contratado por el amo, formaba parte del personal dependiente, en economía y en criterios, de lo que estableciera el amo. De ahí a la actitud de servilismo, tan frecuente por parte de muchos capellanes, tanto en Cuba como en Europa, no había más que un paso.

Antonio Nicolás Duque percibe con claridad el problema, que resta libertad al capellán, y le convierte en mero satélite, limitado en sus movimientos, en sus criterios y en su actuación como evangelizador de los esclavos; tendría que verse forzado a plegar su preocupación por la enseñanza de la doctrina a los intereses económicos de la plantación o los escasas pausas laborales de los esclavos, ordinariamente agotados en el momento del incremento voraz de beneficios.

Precisamente por eso, Duque aconseja que el capellán conserve su libertad de movimientos y de actuación sobre la base de una libertad y autonomía económica que le eviten, además, conflictos con el mayoral. En Duque está hablando una experiencia larga y sensata. De ahí su consejo:

«También [el capellán] (si desea tener paz) ponga especial cuidado en no tener en la hacienda labranza, cría, ceba, ni aun caballo propio, porque éste es el principio indefectible de disgustarse, reñir con el mayo-

24. Pg. 57-58. 
ral, y darle ansia de que asirse 25 de sus operaciones, que le es gravoso» 26 .

Además de la independencia económica, Duque apunta también a la independencia ideológica, de manera que el capellán no aparezca, a los ojos de los esclavos, como un espía del amo; de esta forma, la confianza que podría haber ganado revertiría en perjuicio de los mismos negros, y el capellán quedaría invalidado para la presentación de la fe cristiana, ya que los esclavos le negarían su confianza, al verle como un enviado interesado, de parte del $\mathrm{amo}^{27}$.

Algo que, en principio parece límpido en el pensamiento de Duque es retorcido por Laviña de la forma más desconsiderada e inexacta, llegando al límite de tergiversar por completo el pensamiento de Antonio Nicolás Duque. He aquí las palabras de Laviña:

«Pese al reconocimiento del autor de que los doctrineros tienen como fin primordial "buscar un modesto acomodo que los ponga a cubierto de las escaseces y como objeto secundario y menos principal adoctrinar a los negros"» 28 .

Podría pensarse que cuando Laviña se remite al "autor" hable de Nicolás Duque, pero la cita textual entrecomillada corresponde no a Duque si no a Moreno Fraginals ${ }^{29}$. ¿Cómo es posible semejante equívoco, para dejar pasar por pensamiento de Duque lo que éste no escribió, si el lector no consulta la nota? En todo lo que precede se está refiriendo a Duque, y cuando habla "del autor" parece que hay que seguir pensando en la misma dirección.

En la página siguiente, Laviña se sigue refiriendo inequívocamente a Duque, sobre el mismo tema de la independencia económica, y se expresa de la siguiente forma:

«Indirectamente también nos presenta [Duque] la realidad de las actitudes de los clérigos doctrineros, que buscan solucionar su situación obteniendo una

25. Materialmente, la transcripción pone "asiserse", lo que puede ser defecto del original, o de la propia transcripción.

26. Pg. 69.

27. Pg. $67-68$.

28. Pg. 123.

29. F. Moreno Fraginals, El ingenio. Complejo económico social cubano del azúcar, La Habana, 1978, v. I, p. 117. 
renta extra de las tierras (...) Si el capellán tenía excesiva dependencia del ingenio, estaría en disposición de cuidarse de sus intereses, para lo que necesitaría la ayuda de algún esclavo, con lo que perdería la capacidad de presentarse ante los esclavos como el padre que les protegía, porque verían en él a otro individuo de la plantación pendiente del trabajo y del rendimiento de sus intereses. Por otra parte, si el capellán vivía del trabajo de los esclavos, el mayoral podía controlar mejor la situación del ingenio, y, según Duque de Estrada, la labor evangelizadora quedaría desprestigiada» 30 .

Según Laviña, el objetivo primordial de los capellanes es el acomodo, y el secundario y menos principal es enseñar a los negros. Laviña describe, por tanto, a unos clérigos primordialmente preocupados por sus intereses, y que se tienen que debatir en la duda de si poseer bienes, y, en consecuencia, esclavos para explotarlos, o no poseerlos para no ver malparada su misión (secundaria, no lo olvidemos). Pero si decidieran no poseer bienes propios, tendrían que garantizar su subsistencia sobre la base de un sueldo que les pasara el amo por los servicios prestados: en este caso, habrían marrado su fin primordial, serían libres ante los esclavos, pero carecerían de libertad ante los amos.

¿No podría enfocarse la cuestión de otra forma? ¿No podría ser que las cuestiones económicas tuvieran para los capellanes categoría de "medio" (todo lo importante que se precise) y no de "fin"? ¿No estaríamos ante la imagen de un capellán que dispone de lo suficiente para vivir con dignidad, y que se encuentra con las manos libres para actuar ante el amo sin servilismos y ante los esclavos sin conciencia de explotador? No sería fácil llegar a semejante situación, y menos aún en las plantaciones, alejados de los núcleos urbanos, en la campiña. Pero parece que por ahí apuntan las intenciones y las palabras de Duque. Lo que ocurre es que Laviña no puede disimular su voluntad malévola de esbozar el perfil de unos clérigos interesados por su bienestar, en actitud servil hacia los amos benefactores que les daban su sustento, o convertidos también en explotadores de esclavos, e incoherentes con su predicación.

Lo que Antonio Nicolás Duque afirma es bien distinto de las conclusiones sesgadas que Laviña trata de deducir. Otra cosa bien distinta es que, en la práctica, este equilibrio ideal resultara posible o no, asumido por algunos capellanes, por la mayoría de ellos, o por raras y ejemplares excepciones. Pero eso es, en realidad, lo que Duque presenta, como se verá más adelante.

30. Pg. 124. 
8. Ingenuidad de Antonio Nicolás Duque. Laviña lo afirma en dos ocasiones, pero en una de ellas no aprecio deseo alguno de tergiversar los hechos ni las intenciones, y la "acusación" de ingenuidad, se encuentra, en cierto modo, bien planteada.

En efecto, Laviña describe el cambio que se produjo de una explotación agrícola relativamente rentable, sobre la base del trabajo de los esclavos, a una sobreexplotación de sus fuerzas físicas con el incremento desmesurado y competitivo del cultivo de la caña de azucar, abandonando otras fuentes de ingresos, y sometiendo a los esclavos a un durísimo régimen de trabajo:

«El catecismo escrito por Duque de Estrada fue también una reflexión sobre el cambio de orientación religiosa que afectó a los ingenios. Mientras no fue necesario el tiempo del esclavo para mantener la producción a costos aceptables, los propietarios permitieron que los negros recibieran enseñanza religiosa; pero cuando se exigió del esclavo 16 horas diarias de trabajo, se acabó el tiempo de los sermones»31.

De ahí que Laviña califique a Duque de "aparentemente un clérigo de buena voluntad" y su obra "podría ser calificada de ingenua"32. De ahí la "cierta ingenuidad al pretender la vuelta a la cristianización de los esclavos al estilo que podríamos llamar el antiguo sistema" 33 .

En efecto, hay que convenir con Laviña que Duque, hombre de experiencia, parece haber conocido la situación anterior, en la que la esclavitud -a la que no se puede restar nada de dramatismo- llevaba a cabo un aprovechamiento del trabajo de los negros, con cierta flexibilidad en el esfuerzo, con tiempos de descanso y de ocio, o con una relativa benignidad; esta situación dio paso a un sistema de explotación despiadado y brutal en el que el esclavo era sólo una herramienta de producción. Duque se aferra a lo anterior, y reclama unas condiciones mejores para la educación religiosa que pretende. La ingenuidad consiste en que sabe que se estrella contra un sistema tan despiadado que cuando el negro consigue dejar el trabajo está agotado e incapacitado para prestar atención. $Y$ pese a ello, Duque insiste. Acaso hay que situarlo en la línea de los mejores evangelizadores, que no se arredraron ante dificultades aparentemente insuperables (distancia, lenguas, rechazo, persecución,...). La diferencia es que cuando eso se producía por parte de hombres

31. Pg. 57.

32. Pg. 125 y 124 , respectivamente.

33. Pg. 57. 
libres (a veces no tanto, por haber sido sometidos a conquista) la tarea evangelizadora resultaba ardua pero posible. Pero en el caso presente, la fe cristiana se dirigía a hombres no libres, al borde mismo de la extenuación, y apenas capacitados para asumir las nuevas propuestas religiosas, por el mismo agotamiento unido a la limitación de una lengua impuesta, mal aprendida y peor hablada.

¿Es ingenuo Antonio Nicolás Duque al pretender presentar la fe cristiana a los esclavos en esas circunstancias?

\section{CUESTIONES RELATIVAS A LA TRANSCRIPCIÓN}

Si en las páginas anteriores han aparecido unas cuantas cuestiones en las que no comparto el criterio de fondo expresado por Laviña en la introducción de la obra catequética de Antonio Nicolás Duque de Estrada, a continuación me detendré breves momentos en la cuestión de la forma, o, dicho de otra manera, de la transcripción llevada a cabo. Adolece de algunos defectos insoslayables.

1. Es conocido que no existe una sola normativa para realizar transcripciones, y por tanto Laviña ha podido marcar y seguir las directrices que le hayan parecido mejores. En esto no hay nada que decir. Pero en ocasiones aparecen faltas que más que a la transcripción fiel parecen deberse a fallos mecanográficos, puesto que no realiza ninguna advertencia sobre cómo aparece en el original una palabra defectuosa. Así, cuando aparece tom por toma, más parece que se debe a fallo de la transcripción. No tendría más importancia si no es porque se repite en bastantes ocasiones.

2. Más importante es, a mi entender, el fallo de algunos omisiones importantes. En efecto, en las páginas 61 y 122 de la obra editada por Laviña, aparecen sendas reproducciones de dos páginas que, por figurar al principio y final de la parte transcrita, se supone que son las de portada y conclusión de la obra de Antonio Nicolás Duque. Pero tales páginas no aparecen en la transcripción propiamente dicha.

La reproducción que consta en la página 61 lleva el siguiente texto, que podría ser, incluso por la cuidada disposición del manuscrito, el título de la obra: "Explicación / de la Doctrina Christiana / acomodada / a la capacidad de los Negros / Bozales. / Contiene todo lo que debe saberse / así con necesidad de medio, / como con necesidad de precepto. / Por un Sacerdote / de la congregación del Oratorio / de La Habana." 
El texto de la página 122 dice así: "Si me muriere intestado, entréguese este quadernito al Ilustrisimo Señor Obispo que fuere de este obispado. Antonio Nicolás Duque de Estrada (rubricado)".

A la vista de esto, no hay más remedio que poner en el saldo negativo de Laviña el hecho de haber hurtado al lector dos datos relativos al autor, y uno más concerniente al título. Los dos datos sobre el autor son que no se llama simplemente Nicolás Duque de Estrada sino Antonio Nicolás Duque de Estrada; y que era miembro de la Congregación del Oratorio de la Habana, probablemente el Oratorio de San Felipe Neri. El dato que tiene que ver con el título habla del cuidado puntilloso de Duque de Estrada, quien con un tecnicismo del lenguaje clerical no se quiere limitar a las "verdades [necesarias] con necesidad de medio" (es decir, las verdades que absolutamente deben ser conocidas para alcanzar la salvación), sino que también extiende su preocupación a las "verdades [necesarias] con necesidad de precepto" (es decir, aquellas verdades que deben ser conocidas como consecuencia de un mandato de la Iglesia).

3. Deficiencias en la transcripción propiamente dicha. En principio, y careciendo del original, es obligado suponer que la transcripción es fiable. Sin embargo hay algunos indicios que permiten despertar una sospecha no gratuita. Así, todavía en la introducción, Laviña incluye en la página 52 una cita que reproduce lo que afirma Duque, a fin de exponer su pensamiento; pero he aquí que, cuando tal párrafo aparece en el lugar correspondiente de la transcripción textual (página 72), lo reproducido antes no aparece exactamente igual. ¿Cuál es la versión fiable?

Otros dos indicios que despiertan sospechas son los que figuran en la página 120, al final del texto. En el último párrafo, Duque de Estrada termina su reflexión con una invitación a la misericordia hacia los negros esclavizados, y la remata con una frase evangélica, en latín, de Mt. 5, 7: "Beati misericordes, quoniam ipsi misericordiam consequentur". Pero, inexplicablemente, Laviña ha modificado la primera palabra, haciendo perder sentido a toda la frase, pues en su transcripción consta: "Benedictio misericordes, quoniam ipsi misericordiam consequentur”. Parece más que improbable que Duque de Estrada, hombre de buena formación, como demuestra su escrito, cometiera semejante fallo.

Y, a título de colofón, Duque de Estrada cierra su escrito así: “A. M. D. G.” Laviña, que ha optado por no desatar las abreviaturas, lo hace en esta ocasión con la nada atinada transcripción de "A mayor Dios Gracia", cuando todo el 
mundo sabe que las abreviaturas citadas significan "Ad maiorem Dei gloriam".

4. Por último, Laviña omite cualquier indicación sobre paginación que pudiera constar en el original que transcribe. Tampoco introduce una numeración suya, suficiente identificada, pero orientadora para el lector que no tiene a la vista el manuscrito. Se limita a indicar el cambio de hoja en la paginación por medio de doble barra (//). Pero cuando ha dado ya inicio a la parte del escrito de Duque titulada "Explicación de la doctrina cristiana acomodada a la capacidad de los nogros bozales" (página 77) comienza a figurar una numeración de páginas. Esto desconcierta. Pero lo hace más aún al ver que la página numerada como " 1 " no aparece al principio de este apartado, sino después de una porción de texto de este mismo apartado, anterior a la "1", que podría corresponder al contenido incluido en una página del manuscrito.

\section{QUIÉN ERA ANTONIO NICOLÁS DUQUE DE ESTRADA}

No dispongo de un sólo dato ajeno a su catecismo, que aporte luz sobre el autor del mismo. Por lo tanto, la exigua fuente de información es su propia obra, que, al no ser autobiográfica, apenas ofrece información sobre quien la escribió.

Sin embargo es posible espigar algunos detalles sin proceder caprichosamente. En primer, como ya he indicado, el nombre completo, es Antonio Nicolás Duque de Estrada, y además él mismo deja constancia expresa de que es presbítero y de que pertenece a la Congregación del Oratorio de la Habana. Todo ello consta en las reproducciones no transcritas que aparecen en las páginas 61 y 122. Posiblemente la "Congregación del Oratorio" se refiere a la Congregación del Oratorio de San Felipe Neri, extendida por España. Nada tiene de particular que lo estuviera también por Cuba. De la lectura pausada de su escrito se deduce con claridad que es un clérigo de mentalidad ilustrada, característica del XVIII, en que desarrolló su actividad pastoral: lo demuestra su preocupación por una formación cristiana lo más completa y adaptada posible a los esclavos africanos, y el hecho de no contentarse, como otros hacían, con un bautismo apresurado al poco tiempo de la llegada a la isla, con lo que se ponía fin a todo esfuerzo cristianizador hacia los esclavos.

Además, esa mentalidad ilustrada se concreta en una preocupación catequética clara, inequívoca. Cuando comunica a otros capellanes, junto con amos y mayorales, su interés y su preocupación, lo que está hablando muy 
vivamente es una experiencia personal, dilatada, según la cual no se ha conformado con ir pasando someramente por las diversas situaciones en que se encontraban los esclavos, sino que ha observado y reflexionado sobre ellas, señalando dónde estaban los principales fallos, a la vez que apuntando las posibles soluciones que le dicta su experiencia. Y todo ello lo vuelca en un escrito catequético lleno de intuiciones y aciertos, aunque fuertemente limitados por los condicionantes de la situación ambiental en que se desenvolvía la esclavitud.

Además, Antonio Nicolás Duque deja constancia de la finalidad que le mueve a tomar la pluma. Así, cuando habla de la utilidad de los símiles y comparaciones afirma que esa adaptación, debida al empleo de comparaciones asequibles, así como la de la difícil imitación del lenguaje entrecortado y poco preciso de los esclavos, es su personal aportación al esfuerzo evangelizador: «a lo que se reduce todo lo que se hallará en este quadernito». Con mayor claridad aún se expresa un poco más adelante: «Mi intento no es otro que hacer conocer cómo se les puede hablar sin perder el tiempo y el trabajo. Quiera Nuestro Señor servirse de éste para su mayor gloria. Amén»34.

\section{CARACTERÍSTICAS DEL CAPELLÁN, SEGÚN DUQUE.}

Si lo anteriormente consignado se refiere a la persona del autor, Duque de Estrada, lo que sigue se refiere a él, así como también a cualquier otro capellán que quiera seguir sus pasos y beneficiarse de su influencia. En ningún momento aparece que Antonio Nicolás Duque desempeñara algún puesto de responsabilidad en la organización eclesiástica de La Habana; más bien, la nota final de su manuscrito, pidiendo que, a su muerte, fuera entregado al obispo titular de la diócesis, podría demostrar una lejanía física de la capital de la diócesis, por estar desempeñando su ministerio en haciendas distantes del núcleo urbano. De ahí que su reflexión no es la del superior que instruye a quienes están bajo su mandato, sino la del sacerdote consciente y exigente que trata de comunicar a otros su celo pastoral y el mejor resultado de sus esfuerzos. Precisamente por ello diseña lo que se podría llamar el ideal de un capellán de los ingenios azucareros.

34. Pg. 67 y 70 . 
«Es esencialmente necesario que el Padre Capellán los mire con mucha caridad; no se dexe impresionar de las ponderaciones que hacen de su malicia, que sólo miran sus faltas (...) Hágase cargo de que si el hombre más arrestado tuviera una sola espía de sus acciones (especialmente cuando se está prevenida contra él, como se está contra los negros, hallaría en él muchísimos defectos dignos de corrección, y aun de castigo; pues ¿qué será de los pobres esclavos que tienen tantas espías cuantas son las personas que tienen cargo sobre ellos? Mírelos, vuelvo a decir, con mucha caridad, (...) Intercediendo por ellos (como se ha dicho), disculpándolos, consolándolos, aconsejándolos, socorriéndolos con lo que se pudiera (ellos se conforman con poco), de suerte que vivan confiados del Padre, y lo miren como su paño de lágrimas»35.

Aunque en esta ocasión cambie la expresión del "capellán" por la más genérica de el "catequista", es evidente que se sigue refiriendo también a los capellanes, aunque pueda haber otros catequistas. Su recomendación, reiterativa, es que:

«El catequista los mire con lástima y tenga deseos de que aprendan»36.

Más aún, rehúsa con energía la práctica abusiva de una aparente instrucción religiosa rápida y no muy exigente, al cabo de la cual se procede a un bautismo rutinario y burocratizado, con el que concluye toda instrucción religiosa; es precisamente lo que no debe hacer quien se precie de ser un buen capellán:

«...nace el cruel descuido que hai en instruirlos, aun en las cosas que deben saber y entender con necesidad de medio, para salvarse; contentándose con que digan unas palabras que en algo remeden a las que se les enseñan, para que creyendo el ministro que están instruidos, los bautize, que es hasta donde se extiende el zelo que se tiene de su salvación, sin hacerse cargo de que no basta recibir el bautismo si no se recibe la gracia, y que esto es lo mismo que herrar una res, para embiarla herrada al matadero»37.

Otra condición para el capellán que, por obvia, parece que podría haber omitido, pero que no tiene inconveniente en incluir, es que el capellán -y, por extensión, el catequista-,

35. Pg. 69-70.

36. Pg. 66.

37. Pg. 66. 
«El que enseña entienda lo que dice, y lo sepa decir perfectamente, para que lo diga con sentido y no les enseñe a decir disparates» ${ }^{38}$,

tanto si esos disparates proceden de negros veteranos en la plantación, a los que se les ha confiado la educación de sus nuevos compañeros de esclavitud, como si provienen de blancos (amos, mayorales, capellanes, otros) a los que se supone, por principio, un más elevado nivel de formación general y de conocimientos religiosos. Por tanto, el capellán ha de ser celoso de su deber, y asumirlo personalmente,

«sin dar comisión para eso a un negro, por hábil que sea, ni a un blanco, que para el caso todos son iguales» 39 .

El capellán de la plantación, en su esfuerzo de evangelizar a los negros ha de ser paciente, avanzando poco a poco en el aprendizaje de la fe que presenta, explicando las cosas con paciencia, y apoyándose en los resultados anteriores que se hayan consolidado, sin querer ir más deprisa de lo que permita el aprendizaje real de los negros. Además, como ya ha aparecido, la recomendación es que se sirva de los símiles y comparaciones, para lo que Duque brinda las que a él resultan útiles, para que otros se puedan servir de ellas.

Aparentemente, el capellán ha de adoptar ante los negros una postura de un cierto distanciamiento, sin darles la razón por principio, ni aceptar ser su padrino, e incluso aceptando, con una calculada pasividad, los castigos corporales que se les puedan infligir. Pese a esa supuesta indiferencia, que evitaría una postura de excesiva intervención por parte del capellán, la verdadera recomendación que Duque hace es que

«es esencialmente necesario que el padre capellán los mire con mucha caridad»,

y que, aunque se haga de rogar en las súplicas de los esclavos,

«no dexe de interceder por ellos» 40 .

38. Pg. 66.

39. Pg. 67.

40. Pg. 69. 
Finalmente, recomienda que sea enérgico con los negros en lo relativo a la asistencia a misa, pues con mucha facilidad la descuidan, con la consecuencia de un teórico aprendizaje que no tiene después repercusión práctica; llega a recomendar que a los atrasados en la doctrina se les reprenda ("reprehenda", sic), se les imponga alguna penitencia (ponerles de rodillas o besar la mano de quien contestó bien lo que otro dijo mal) o incluso con algunos "torniscones" (pellizcos) ${ }^{41}$.

La conclusión de la imagen que Duque traza del capellán o doctrinero, aunque en algún momento se haga extensiva también a otras personas (p. ej., "catequistas") es valiosa, acertada, y exigente, como corresponde a un hombre que no se conforma con hacer las cosas en plan de mero cumplimiento, sino desde la exigencia de llevar a cabo su auténtica obligación. Las palabras conclusivas del tratado, dirigidas a los capellanes, cierran, mejor que cualquier otra reflexión mía, lo que constituyó la verdadera intención de Antonio Nicolás Duque:

«Hasta aquí, mis venerados capellanes, he puesto a vuestra consideración lo que he juzgado a propósito para que os hagáis cargo del modo con que podéis cumplir con vuestro deber, ganar mucho cielo y ser útiles al público, en una materia en que sólo vosotros lo podéis ser. Pero para cumplimiento de todo debo advertiros que de nada servirá lo dicho, si faltara en vosotros la constancia en [que] esencialmente consiste la consecución del fin que se pretende: quiero decir que (siempre que podáis celebrar) por ningún motivo se ha de dexar de decir algo a los negros (aunque sea muy poco), relativo a su instrucción, de suerte que ellos conozcan el cuidado que deben poner en aprender del que el padre pone en enseñar. No hai exortación más eficaz que la del exemplo, y convendrá que esto se les advierta. Con esta circunstancia se habituarán ellos a recoger, y el padre a reparar el divino pasto; y si se falta a eso un solo día, aunque el motivo parezca el más racional, al día siguiente subsistirá la misma causa, o se ofrecerá otra que parezca de mayor consideración, y en dejando de enseñar tres o quatro días, basta para contraer hábito de faltar a esto, o por lo menos de no hacerlo con el tesón que es necesario.

41. Pg. 70. En pg. 108-109 ofrece una serie de razones válidas para que comprendan la importancia de la misa; no se trata sólo del empleo de métodos coercitivos, sino que se complementan con expliçaciones muy aceptables: « $i \mathrm{Y}$ [h]ay cristianos que pierden la misa por cosa de bobería? Porque va a buscar cabeza de ñame, porque va a buscar basura de tabaco, porque va a mirar a su madrina, porque va a remendar sus cañamazos, porque se va a chapear o a quemar la manigua del conuco? (...) Primero va a misa, y luego va a buscar cabezas de ñame; primero oye misa, y luego va a buscar basura de tabaco; primero oye misa, y luego va a quemar manigua o a chapear el conuco. Misa primero, primero; Misa no se pierde nunca, por nada se pierde misa». 
Ruegos [=ruégoos] por las entrañas de nuestro Señor Jesucristo y por el deseo que sentís de alcanzar misericordia, que la tengáis de estos pobrecitos (que muchos de ellos se condenan por falta de instrucción), para que nuestro Señor la tenga con vosotros según su divina palabra: Beati misericordes, quoniam ipsi misericordiam consequentur $\gg{ }^{42}$.

A la vista de estos trazos sobre la figura del capellán, según las mismas expresiones de Duque, es muy poco inteligible la postura de Laviña al afirmar que el fin primordial de los doctrineros consistía en buscar acomodo ante sus necesidades, o despertar el interés de los amos para que mantuvieran a los doctrineros; más aún, la supuesta "profesionalización" del capellán, que excluía que otras personas intervinieran en la presentación de la fe, «porque dicen disparates», según la expresión de Duque, es trastocada por Laviña, en el sentido de que pretendían eliminar posibles competidores, $\mathrm{y}$ «de esta forma se haría imprescindible la figura del capellán en el ingenio»43. Inaceptable manipulación.

\section{CONSIDERACIÓN DEL NEGRO, SEGÚN DUQUE}

¿Cuál es la concepción que Antonio Nicolás Duque tiene del negro al que destina sus esfuerzos evangelizadores, directamente o de modo indirecto a través de otras personas (otros amos o capellanes)?

Lo primero que es preciso afirmar con rotundidad es que Duque se niega a aceptar una consideración, ampliamente extendida, incluso entre otros capellanes, según la cual los negros eran incapaces de comprender la fe cristiana que se les presentaba:

«Es persuasión común que los negros no pueden comprehender la doctrina christiana, y que ni aun son capaces de pronunciar lo que se les enseña»44.

En abierta oposición a semejante consideración peyorativa, Duque aduce una poderosa razón que explica las dificultades de entendimiento y de pronunciación: no saben el castellano. Han tenido que aprenderlo a trompicones, de modo forzado, sin explicaciones progresivas y lógicas que se les hubieran

42. Pg. 120.

43. Pg. 123 y 125.

44. Pg. 66. 
presentado en sus lenguas de origen; además, los esclavos adultos habían sido arrancados violentamente de sus tierras, en las que habían aprendido en su infancia otras lenguas de estructura radicalmente diversa. ¿Cómo podían llegar a saber, repetir y entender lo que se les decía en un idioma desconocido? Procediendo a la inversa, un "culto" blanco que hubiera sido atrapado y esclavizado en el interior de África, ¿no hubiera sido tachado de "incapaz" ante las dificultades de comprensión y expresión?

Duque es perfectamente capaz de caer en la cuenta de la degradante situación en que se encuentran los esclavos, sometidos a trabajos sin cuento, privados de consideración y de cualquier tipo de miramiento, que no fueran los encaminados a aumentar su rentabilidad económica. Frente al hecho, Duque no ha perdido el criterio adecuado, y en una de las recomendaciones que hace a los capellanes, les dice que miren a los esclavos con toda caridad -ya ha aparecido-, y añade la razón de semejante consideración, con una expresión sorprendentemente moderna para su época, tanto por el fondo como por la forma:

«Mírelos, vuelvo a decir, con mucha caridad, como a personas miserables, dignas de la mayor consideración» 45 .

En la expresión hay que considerar la doble apreciación que encierra: por un lado son "miserables" como reconocimiento de un hecho calamitoso, cual es la esclavitud, y las condiciones infamantes que establecía para sus víctimas; pero, por otro lado, estos esclavos son "personas dignas de la mayor consideración". Encontrar este pensamiento en el siglo XVIII, poco tiempo después de la Revolución Francesa, aplicado en concreto a unos esclavos, supone tener que admitir el convencimiento ilustrado de Duque, para quien la certeza de que cualquier persona es digna de la máxima consideración se hace extensiva incluso a los esclavos, a los que se negaba, en la práctica, semejante calidad 46 .

45. Pg. 70.

46. La lenta marcha de la abolición de la esclavitud está plagada de declaraciones poco efectivas, aunque bien planteadas. La Virginia Bill of Rights (1776) afirma en su sección $1^{\text {a }}$ que «... all men are by nature equally free and independent and have certain inherent rights...»; la Declaración de los Derechos del Hombre y del Ciudadano, a raíz de la Revolución Franciesa (26 de agosto 1786) reconoce que «los hombres nacen y permanecen libres e iguales en derechos. Las distinciones sociales sólo se pueden basar en consideraciones del bien común». La abolición teórica de la esclavitud se produjo en 1792 en Dinamarca, en 1807 en Gran Bretaña, en 1808 en Estados Unidos, en 1848 en Francia, en 1861 en Rusia, en 1863 en Holanda, y en 
Por si aún pudiera caber alguna duda sobre la consideración que Duque tenía respecto a los esclavos con los que desarrollaba su actividad pastoral, hay otras palabras de su escrito que matizan más el aprecio en que los situaba:

«A la verdad esta actitud47, (que la juzgo obligatoria), no puede tenerla quien no reflexione, que cada negro tiene un alma racional, es decir, un vaso precioso en que está depositada la sangre adorable de Jesucristo nuestro Señor, que murió por ellos» 48 .

Si la frase anterior, que hacía referencia a la condición de personas, reconocida también a los esclavos, podía ser suscrita por creyentes y no creyentes, sin excepción, la frase última representa un pensamiento específicamente religioso, con arreglo al cual, la consideración ya elevada de persona queda aún más dignificada por el hecho de que cada esclavo, cada negro, tiene un alma racional, por cuya salvación murió Cristo. Hay una clara resonancia de Ga. 3, 28: «ya no hay judío ni griego; ni esclavo ni libre; ni hombre ni mujer, ya que todos vosotros sois uno en Cristo Jesús». Y si no existen diferencias ante Dios por la condición externa de los hombres, la razón hay que encontrarla en $\mathrm{Rm}$, 5, 6-8: «En efecto, cuando todavía estábamos sin fuerzas, en el tiempo señalado, Cristo murió por los impíos; -en verdad, apenas habrá quien muera por un justo; por un hombre de bien tal vez se atrevería uno a morir -; más la prueba de que Dios nos ama es que Cristo, siendo nosotros todavía pecadores, murió por nosotros».

1872 en Cuba, tras la proclamación de la $1^{\text {a }}$ República Española. En las antiguas colonias de Sudamérica se produjo la abolición en el momento de conseguir la independencia, salvo en Brasil, donde se mantuvo hasta 1888 .

En Estados Unidos, sin embargo, pese a la declaración de 1808 se continuaba manteniendo en grandes proporciones en los estados del Sur. Tras la batalla de Gettysburg (1863), al final de la Guerra de Secesión, tuvo lugar la proclama antiesclavista de Lincoln, y se produjo la consiguiente liberación de importantes contingentes de esclavos en los estados sureños.

Desde los tiempos de Antonio Nicolás Duque no era posible soñar con el fin de la esclavitud. Aún hubo de pasar siglo y medio para que la Declaración universal de los derechos humanos, el 10 de diciembre de 1948, recogiera en su artículo $4^{\circ}$ : «Nadie estará sometido a esclavitud ni a servidumbre; la esclavitud y la trata de esclavos están prohibidas en todas sus formas»

47. En la transcripción, Laviña escribe "esta exactitud"; yo creo que se trata de un error, y que la palabra más adecuada sería "actitud", aunque no he podido cotejarlo con el manuscrito original.

48. Pg. 67. 
Para Duque, estén bautizados o no, los esclavos son personas, y además son destinatarios del amor desmedido y generoso de Cristo, entregando su vida por todos. De ahí el aprecio irrenunciable que a Duque le suscitan. Y es lógico que se duela de la injusta situación en que se ven envueltos a su pesar; por ello se lamenta: «iPobres esclavos!»49; «...estos pobrecitos»50.

\section{ANÁLISIS GLOBAL DE LA OBRA DE ANTONIO NICOLÁS DUQUE DE ESTRADA}

A mi modo de ver, la consideración efectuada por Laviña en el apartado tercero de su introducción, titulado "Iglesia y esclavitud" resulta superficial en muchos aspectos y carece del rigor de un análisis como se merece un catecismo, desde el punto de vista de la catequética. Voy a proceder, por tanto al análisis de lo que Duque escribió.

1. Esquema. La primera apreciación, desorientadora, al examinar su obra, es la de una evidente falta de orden. Presento a doble columna el esquema con que aparecen las diversas partes en la obra de Duque de Estrada con sus respectivos títulos (izquierda), complementado con lo que parece que debería ser el orden lógico (derecha):

\begin{tabular}{|c|c|c|c|}
\hline \multicolumn{2}{|r|}{ ESQUEMA DE LA OBRA } & \multicolumn{2}{|r|}{ ORDEN LÓGICO } \\
\hline 1 & [Catecismo] (p. 63-66) & 1 & Prólogo (p. 66-70) \\
\hline 2 & Prólogo (p. 66-70) & 2 & Instrucción para los que se dedican a \\
\hline 3 & $\begin{array}{l}\text { Instrucción para los que se dedican a } \\
\text { enseñar a rezar las oraciones y } \\
\text { Catecismo (p. 71-75) }\end{array}$ & 3 & $\begin{array}{l}\text { enseñar a rezar las oraciones y Catecismo } \\
\text { (p. } 71-75) \\
{[\text { Catecismo }] \text { (p. 63-66) }}\end{array}$ \\
\hline 4 & $\begin{array}{l}\text { Explicación de la doctrina christiana } \\
\text { acomodada a la capacidad de los negros } \\
\text { bozales (p. 77-103) }\end{array}$ & 4 & $\begin{array}{l}\text { Explicación de la doctrina christiana aco- } \\
\text { modada a la capacidad de los negros } \\
\text { bozales (p. } 77-103 \text { ) }\end{array}$ \\
\hline 5 & $\begin{array}{l}\text { Para que sepan que deben saber y enten- } \\
\text { der la Doctrina Christiana... (p. 103-120) }\end{array}$ & 5 & $\begin{array}{l}\text { Para que sepan que deben saber y enten- } \\
\text { der la Doctrina Christiana... (p. 103-120) }\end{array}$ \\
\hline
\end{tabular}

49. Pg. 110.

50. Pg. 120. No entiendo que Laviña despache el tema apuntando que «los clérigos de ingenio veían en el africano una fuente de vicios y casi imposible de que llegasen a la comprensión mínima de la religión, e incluso por lo que apunta Duque, tenían dudas sobre la condición humana del negro» (Pg. 125). No aparece ni una palabra sobre el valor individual que Duque atribuye a los negros. Cabría pensar que Laviña da a entender que Duque participa de la situación ambiental, al no hacer otras precisiones. 
Parece lógico pensar que el prólogo (y la instrucción que le sigue) vayan al principio; sin embargo, el propio texto de la obra certifica en dos ocasiones que el catecismo precede al prólogo ${ }^{51}$ por lo que orden real y orden lógico no se corresponden. Es más, es posible que en el manuscrito (quizá no en las ediciones impresas), destinado para uso personal del autor, hubiera un cierto "desorden" que a él mismo no le suponía demasiada incomodidad. En el mismo manuscrito hay llamadas internas, de una página a otra, en varios momentos, lo que supone que Antonio Nicolás Duque escribió el manuscrito sin pensar demasiado directamente en el uso que se podría dar en una publicación.

La parte que he denominado [Catecismo] es la que corresponde a las preguntas y respuestas iniciales; en el manuscrito no lleva título alguno. Pero lo cierto es que es designado en los dos lugares aludidos en la nota anterior como "el Catecismo que está al principio", lo que no ofrece duda alguna a la hora de asignarle un título que Duque omitió en su momento. También el título de la Instrucción hace referencia al innominado Catecismo. De momento sirve la idea de que no se trata más que de suplir la omisión de Duque.

He diferenciado también la parte quinta, segregándola de la parte cuarta. En realidad, la parte quinta está constituida no por un apartado, sino por una serie de ellos, cada uno de los cuales lleva su correspondiente título. Estos son:

- Para que sepan que deben saber y entender la Doctrina Christiana (p. 103-109);

- Para que hagan sus obras con provecho (p. 109-111);

- Sobre el Padrenuestro (p. 111);

- Ave María y Salve Regina (p. 112);

- Sobre el baptismo (p. 112-114);

- Sobre la eucharistía (p. 114-115);

- Sobre los mandamientos (p. 115-120).

La razón de segregar todo lo anterior de la parte cuarta, es que ésta se refiere a las preguntas del Catecismo inicial, que explica por medio de otras preguntas y respuestas más amplias; por el contrario las últimas reflexiones son expositivas, y, en cierto modo, autónomas, porque no se refieren a alguna pregunta en particular.

2. Estilo. En la obra de Duque se aprecian con claridad dos estilos que se superponen. Uno es un estilo que podría denominarse "culto", dirigido a los 
capellanes, a los amos y mayorales, exponiendo por dónde debe discurrir la enseñanza de la fe cristiana, y las razones generales o particulares para proceder de una determinada manera en un punto concreto. Este estilo culto se sirve de una redacción correcta del castellano utilizado, con frases bien construidas y redactadas. Ordinariamente huye de tecnicismos y expresiones rebuscadas, menos en aquellas ocasiones en que la exposición misma de la fe obliga a utilizarlas: tal es el caso de tener que hablar de que Jesucristo "tomó la naturaleza humana".

El otro estilo empleado es el que podría denominarse como "negro", dirigido a los esclavos; se caracteriza por ser repetitivo, por carecer de sintaxis adecuada, por omitir algunos miembros de la frase (artículos, preposiciones), de manera que surge una frase entrecortada, balbuciente y poco exacta (Duque insistirá en ese aspecto) pero que recoge muy bien el habla insegura, fragmentaria y empobrecida que los esclavos utilizaban a medida que iban aprendiendo un castellano deficitario, pero con el que podían entender y ser entendidos. Duque demuestra con ello unas exquisitas dotes de observador, además de una larga práctica pastoral al lado de los esclavos, al recoger con fidelidad ese estilo de expresión tan típico.

Cada una de las partes diferenciadas en el esquema de la obra de Duque están redactadas en un estilo (por ejemplo, el Prólogo está redactado en estilo culto, y la Explicación aparece en estilo "negro"). Pero no es raro el paso de uno a otro, porque cuando Duque está dando explicaciones a los capellanes sobre lo que deben hacer o decir, acude a las expresiones usadas por los esclavos, a fin de facilitar la labor del capellán, y que éste pueda ser entendido por los negros en su jerga. Ejemplo de lo dicho puede ser el siguiente párrafo, tomado del Prólogo:

«Nunca les dé [el capellán] la razón cuando se quejan del mayoral, aunque conosca que la queja es justa, por no darle[s] alas (como dicen) sino procurar disculpar al mayoral; puede decirles (sin negarles la justicia): ustedes mismos tienen la culpa, porque no todos cumplen con su obligación. Ustedes son muchos; el mayoral uno no más; hoi falta uno, mañana falta otro. Otro día tiene uno una picardía, otro día la hace otro. Todos los días tiene mayoral que aguantar; esto todos los dias, todos los dias, más que no quiera, preciso, se pone bravo. Masa Buei es manzo, si siempre están jinca, jinca, él tira patadas, preciso; mismo son mayoral: un día puede aguantar mucho, otro día no puede aguantar ni poquito tampoco, porque ya barriga está llena» 52 .

52. Pg. 69. 
Lo destacado con cursiva corresponde a la parte de estilo "negro", entremezclado con el otro estilo culto que Duque utiliza. Sin embargo, llama la atención que en la forma culta de expresión, Duque se sirve de algunos arcaísmos. En el XVIII era frecuente escribir "christiano" o "quando", como hace Duque; pero no resultaba ya ordinario el uso de "eucharistía" (por eucaristía), o de "baptismo" (por bautismo), o de "hai" (por hay), o "fembra" (por hembra), o "fizo" (por hizo). Aunque no llama demasiado la atención, puesto que la decantación progresiva de la ortografía permitía una gran flexibilidad. Es precisamente esta permisividad en el empleo del castellano culto, junto con el abundante empleo del estilo que he denominado "negro", donde aparece "manzo" (por manso) o "cortecía" (por cortesía), lo que da al conjunto del escrito de Duque un estilo arcaizante e ingenuo, peculiar porque lo diferencia de otros escritos de la misma época que no incorporan la jerga peculiar de los esclavos africanos.

3. Expresiones no frecuentes en los catecismos. Es muy frecuente en el escrito de Duque acudir a numerosas expresiones, y especialmente a numerosos substantivos que rara vez se encuentran en otros catecismos; ésta es una característica que diversifica el escrito de Duque de Estrada con relación a los demás catecismos.

Entre tales expresiones se puede hacer una doble clasificación. Por una parte una larga lista de palabras procedentes del ambiente cubano en que surgió en escrito, y que no son entendibles fuera de él. Así es posible poner de ejemplo la palabra "cuje" con el significado de «vara horizontal que se coloca sobre otras dos verticales, en la que se cuelgan las mancuernas en la recolección del tabaco», típico de las explotaciones agrícolas. Es larga la lista de estos vocablos, poco usuales en catecismos, algunos de los cuales resultan desconocidos fuera del ambiente caribeño.

Por otra parte, aparecen con frecuencia algunos otros substantivos, cuyo significado no ofrece dificultad alguna, pero que, además de no ser frecuentes en los catecismos, son utilizados en el presente con mucha frecuencia para designar diversos aspectos o ejemplos que tienen que ver con la formación religiosa de los esclavos. Tal puede ser el caso de la palabra "mula". Es empleada por Duque para afirmar que, cuando se hizo hombre, Jesucristo tomó la naturaleza humana: «Aora: Dios Hijo no tomó naturaleza de caballo ni de mula, ni de perro, sino naturaleza de hombre, que eso es naturaleza humana»53. Cuando habla del desconocimiento del castellano por parte de los 
esclavos, dice: «Quando la gente le dice cómo te llamas?, él también dice palabra mismo: "Cómo te llamas?". Pero él no entiende ninguno. Si le dice Mula, él también fabla "Mula"»54. A la hora de invitar a que hagan las obras que Dios espera de ellos: «es preciso que faga las cosas como gente, no como mula. La gente quando face una cosa, sabe lo que face y a quien sirve. La mula no sabe ni qué amo tiene ni sabe a quien sirve, ni qué va a facer; ni sabe si lo que face es bueno, o si es malo. En faciendo así como mula se pierde el trabajo. La gente si va a comer sabe que la comida es buena para mantener la vida del cuerpo, y el cristiano que quiere servir a Dios no como como la mula (porque tiene gana), sino porque es preciso mantener la vida del cuerpo (...) Si trabaja sin pensar que eso es bueno para servir a Dios, trabaja como mula; pero si él piensa...no trabaxen como mula»55.

4. Dificultad idiomática. Duque es consciente de la enorme dificultad que padecían los esclavos negros para entender el castellano y para expresarse en él; por consiguiente la misma o mayor dificultad aún existía cuando se tratada de presentarles en esa lengua la doctrina cristiana. Duque no muestra ningún atisbo en su escrito de intentar expresarse en la lengua de los negros. Pero la razón es clara. No se trata de negarse a hacer un esfuerzo-ingente-de adaptación por medio del empleo de otra lengua. Ocurre, más bien, que esto resultaba imposible. En efecto ha aparecido ya el cuidadoso interés de los propietarios cuando adquirían nuevos esclavos de seleccionarlos de diversas etnias (terminaban por ser trágicamente "expertos" en el tema) para evitar la comunicación entre ellos por el hecho de proceder de pueblos diversos y hablar lenguas también diversas. Tenían en común el color de su piel y su condición de esclavos, pero resultaban entre sí tan ajenos como puede serlo un alemán, un griego y un inglés, todos de raza blanca. En estas condiciones, procedentes de tierras donde se hablaban lenguas que nada tenían que ver con el castellano, se veían obligados a tener que aprender a la fuerza (a veces a puro látigo) y siempre mal, sin explicaciones, ni tiempo, ni cuidado, una lengua perfectamente desconocida. Por más que lo hubiera intentado, ¿en qué lengua podría dirigirse Duque a los esclavos si hubiera decidido emplear una de las muchas que éstos hablaban, según su procedencia?

Su deficiente castellano era la consecuencia inevitable. El ejemplo anteriormente aducido del negro que oía «¿Cómo te llamas?»Y repetía «¿Cómo

54. Pg. 103.

55. Pg. 109-110. 
te llamas?», en lugar de decir su nombre, o que oía «Mula» y también repetía «Mula» como si ese fuera su nombre propio, muestra toda la crudeza de unos hombres y mujeres desenraizados y obligados a acceder, por pura necesidad, a una lengua desconocida.

Otro ejemplo más evidencia esta grave dificultad: «Así como no se contentan los amos con que los esclavos sepan decir cama, silla, mesa, sin[o] que enseñándolos a pronunciar les dicen, mostrándoles las cosas, mira: esto es o se llama cama, esto, plato, esto, cuchillo, y así todo de lo demás, para que quando les digan friega el plato, trahe el cuchillo, haz la cama, entiendan y hagan lo que se les manda,...»56.

Ante semejante panorama idiomático, ¿cómo podrían aprender los negros una religión extraña? ¿Y cómo podrían llegar a entenderla?

Duque se esfuerza en salir al paso de este problema, llamando la atención de los responsables de la evangelización (capellanes, amos) sobre la cuestión de reclamar precisión en palabras que fonéticamente son parecidas, pero que tienen significados diversos, para, de esta manera, evitar equívocos lamentables. Propone el siguiente ejemplo:«Tú no sabes agua? Tú no sabes yagua?. Responderá que sí. Pues dime: agua y yagua es lo mismo, mismo? No; una cosa es agua para beber, y otra es yagua para caballete de bujío»57. El uso del castellano, como lengua neutral para cada uno de los esclavos, e igualmente extraña para todos ellos, fue la forma elegida por Duque para la exposición de la fe cristiana, sin pararse a plantear otra cuestión sobre si era procedente hacerlo en otra lengua. Posiblemente él mismo desconocía las variadas lenguas de origen de los esclavos a quienes trataba de enseñar. El esfuerzo de Duque se concreta en el empleo adecuado para expresar bien la fe cristiana, y en la pronunciación y aprendizaje adecuados, como se verá más adelante.

5. Empleo de comparaciones. Consecuencia de la dificultad idiomática, y de la consiguiente dificultad conceptual, Duque opta por el empleo de un recurso ampliamente utilizado por la catequesis de todas las épocas: el de las comparaciones o símiles. Lo cierto es que son muchas las comparaciones que emplea, posiblemente más que otro catecismo conocido, de una extensión equivalente a la del texto de Duque. Cuando Laviña se ocupa casi de pasada en este aspecto, después de haber hablado de la "buena voluntad" de Duque de Estrada, añade: «establece las curiosas comparaciones que he apuntado en

56. Pg. 72.

57. Pg. 67. Yagua es "palma que sirve de hortaliza, y con la cual se techan las chozas de los indios y se hacen cestos, sombreros y cabuyas». 
las páginas anteriores ${ }^{58}$. Lo cierto es que es una pobre apreciación de este recurso, ingeniosa y abundantemente empleado por Duque.

El mismo Duque razona su utilización de la siguiente manera, perfectamente trabada y meditada:

«Para que entiendan es menester valerse de símiles caseros, y, en cuanto sea posible, de aquellas cosas que ellos manejan: como el buey, la yegua, el bujío, el conuco, las pailas, etc, y quanto se pudiere acomodar y hablarles en aquel lenguaje que usan ellos sin casos, ni tiempos, sin conjunciones, sin concordancias, sin orden, a lo que se reduce todo lo que se hallará en este quadernito» ${ }^{59}$.

Hay, por tanto, tres aspectos a considerar en estas palabras: $1^{\circ}$ el esfuerzo de acomodación que Duque considera irrenunciable; $2^{\circ}$ la recomendación a acudir a lo que les resulta familiar, "casero", es decir, lo que está ceñido al reducido universo de la plantación; $3^{\circ}$, dentro de este microcosmos, es preciso acudir al aún más restringido universo de lo que el esclavo conoce y maneja, lo que impone severas limitaciones a las comparaciones que se puedan utilizar. El universo de los esclavos negros en las plantaciones de la campiña, a distancia de cualquier núcleo urbano quedaba reducido al trabajo, a la precaria economía que los esclavos podían manejar, a los animales que utilizaban en las faenas agrícolas, a los propios animales que poseían en propiedad para complementar su subsistencia, a la preocupación por su propia salud y por la precaria salubridad en que se desenvolvían 60.

Con tan fuertes limitaciones, Duque demuestra todo un derroche de esfuerzo e imaginación para recurrir de modo casi constante a las comparaciones, y aconsejar a otros evangelizadores que hicieran otro tanto, o que se sirvieran de las comparaciones y símiles que él había usado. He aquí la larga lista de las comparaciones del texto de Duque:

58. Pg. 125.

59. Pg. 67.

60. Laviña (pg. 33 y ss) aborda la cuestión de la esclavitud y vida cotidiana. Describe que en la época de no excesiva presión productiva, los esclavos disponían de una choza o "conuco" (también llamado "bujío", como equivalente a "bohío"), de algunos animales domésticos, de una pequeña parcela en la que cultivaban algunas legumbres y hortalizas para complementar la dieta que les proporcionaban los amos; y que disponían de una pequeña cantidad de dinero, con la que aspirar a comprar su libertad, además de su prestación laboral. Estas pequeñas propiedades dibujan un panorama casi idílico en comparación con los cambios operados con el auge de la explotación para la producción masiva de azúcar, pues entonces se endurecieron sus condiciones de vida, confinados a reductos cerrados para evitar fugas, a carencia de tiempo para sus propios cultivos, y a prescindir del sueño de alcanzar la libertad en un régimen de explotación feroz que apuraba sus energías hasta el agotamiento. 
PÁG

\section{COMPARACIÓN}

66 El esclavo que recibe el bautismo sin instrucción es como la res herrada para el matadero

67 Corrección de errores al decir palabras parecidas: agua - yagua

71 Tres huesos y un sólo dedo para hablar de tres Personas y un solo Dios

73 Enseñarles con calma, como hay que echar con calma el agua en un frasco de boca estrecha

74 Diversos materiales para construir una casa como ejemplo de las diversas cosas de la fe

77 Dios está en todas partes, como la luz del sol da en el agua o en el fuego

78 Dios hace las cosas de la nada; el artesano hace su labor con materiales disponibles

79 En un huevo hay clara, yema y cáscara, como en un solo Dios hay tres personas

79 En un fruto hay cáscara, pepita y comida, como en un solo Dios hay tres personas

81 Jesús es uno solo, Dios y hombre, como yo soy uno solo, compuesto de alma y cuerpo

82 Jesús tiene naturaleza humana como cada animal tiene su propia naturaleza

83 María parió quedando virgen (doncella), como la luz sale del farol

85 Jesús fue castigado por Poncio Pilato como el esclavo es castigado por el mayoral

88 Jesús tomará cuentas a los hombres como el mayoral toma cuentas a los esclavos

90 Hay que hacer lo que mandan Dios y la Iglesia como hay que hacer lo que manda el amo

91 Somos redimidos por Jesús, como el asesino que es indultado por el rey de la pena de muerte

91 El pecado venial exige un castigo, como a los muchachos se les castiga para educarlos

91 El purgatorio es como la casa de purga, donde se purifica al azúcar para blanquearla

92 Todos los dedos hacen una mano; todos los cristianos hacen una Iglesia

92 Todos los miembros hacen un cuerpo; todos los cristianos hacen una Iglesia

92 Cristo es cabeza de la Iglesia, pero gobierna el papa, como el amo delega en el mayoral

93 Cristo está en cada partícula de la eucaristía como cada trozo de espejo refleja toda la imagen 
PÁG

COMPARACIÓN

\begin{tabular}{|cl|}
\hline 95 & $\begin{array}{l}\text { Los sacramentos son remedios para el alma como las boticas son remedios } \\
\text { para el cuerpo }\end{array}$ \\
\hline 96 & $\begin{array}{l}\text { Acordarse de los pecados, como acordarse de los lugares donde pudo perder } \\
\text { el tabaco }\end{array}$ \\
\hline 97 & $\begin{array}{l}\text { La confesión ajusta cuentas con Dios, como se ajustan cuentas pendientes con } \\
\text { el tabernero }\end{array}$ \\
\hline 98 & Como el amo perdona al esclavo que reconoce su culpa, así perdona Dios \\
\hline 99 & No volver a confiar en quien gastó mi dinero; propósito de no volver a pecar \\
\hline 99 & $\begin{array}{l}\text { Horcas ("forcones") sostienen la techumbre del bujío; propósito firme sostie- } \\
\text { ne al pecador }\end{array}$ \\
\hline 100 & $\begin{array}{l}\text { Propósito de no pecar es como propósito de no volver al barrizal donde se } \\
\text { atascó la yegua }\end{array}$ \\
\hline 102 & $\begin{array}{l}\text { El esclavo mandado por el amo a La Habana es como el cristiano que no está } \\
\text { en el cielo }\end{array}$ \\
\hline 103 & $\begin{array}{l}\text { Deseo de saber la doctrina como la gente que mira con ansia la comida } \\
\text { con los ojos }\end{array}$ \\
\hline 104 & $\begin{array}{l}\text { El hombre es responsable de sus actos, como el esclavo que se niega a comer } \\
\text { lo que le dan }\end{array}$ \\
\hline 104 & No sirve no retener y olvidar la doctrina; como no sirve comer y vomitar \\
\hline 104 & Insistencia en aprender la doctrina, como la soga roza el palo y lo desgasta \\
\hline 107 & $\begin{array}{l}\text { El esclavo es cortés con su amo; debe serlo también con Dios, acudiendo a } \\
\text { misa }\end{array}$ \\
\hline 107 & Debemos pedir todo a Dios como el niño pequeño que necesita de todo \\
\hline 109 & $\begin{array}{l}\text { Quienes no se preocupan de su alma son como los que buscan comida al perro } \\
\text { y no a su hijo }\end{array}$ \\
\hline 110 & Hay que servir a Dios, aunque no lo necesite, como el esclavo hace regalos al amo \\
\hline 112 & Saludo a María, como los esclavos saludan al amo al hablar con él \\
\hline 113 & Pecado original desde el nacimiento, igual que son negros desde el nacimiento \\
\hline 114 & Dios es más bueno que el amo bueno, que da al esclavo lo que necesita \\
\hline 115 & La eucaristía da fuerzas al alma, como la comida ayuda a recuperar al enfermo \\
\hline 115 & Si dos luchan, pierde el débil; los sacramentos dan fuerza al débil \\
\hline 116 & Amar al prójimo es quererle, como el hombre casado quiere a la mujer buena \\
\hline 117 & Eo debemos tratar mal al prójimo, como no queremos que nos traten mal \\
\hline
\end{tabular}


No se puede decir que Duque no puso en actividad su imaginación y sus recursos para, en un universo tan limitado como el de los esclavos africanos, poder echar mano de tan amplio surtido de comparaciones; es verdad que todas no son originales de él, y que algunas eran lugares comunes de los catecismos (María quedó virgen tras el parto como la luz que sale del farol, o «el rayo de sol sale por un cristal sin romperlo ni mancharlo»61). Pero nada impide el reconocimiento al esfuerzo de Duque, que afronta el recurso copioso a las comparaciones a partir de un mundo extraordinariamente reducido.

6. Carencia de una invitación libre al cristianismo. Hoy, ciertamente, hubiera sido inevitable hacer una invitación de esta índole a los destinatarios del catecismo, para que aceptaran o rechazaran la fe que se les proponía, con pleno conocimiento y en el respeto a su decisión. Pero hoy estamos situados en otra perspectiva de la que no gozó Antonio Nicolás Duque en el momento de escribir su catecismo.

No aparece en su reflexión una religión planteada como una oferta libre que el hombre puede rechazar o aceptar, aunque aparezcan las consecuencias de castigo o premio derivadas de la actitud que el hombre emprenda ante Dios. No se encuentra expresamente escrito el concepto de "libertad" como una de las cualidades que posee el hombre, porque hacer una afirmación así resultaba contradictorio a unos esclavos privados de libertad. Por consiguiente, lo único que aparece es la capacidad de decidir el comportamiento bueno o malo, con arreglo a los dictados de Dios, que lleva aparejado el juicio equitativo y sancionador de quien conoce las intenciones del ser humano.

Tampoco aparece para nada alguna referencia a la vida religiosa o a las prácticas religiosas que hubieran efectuado los actuales esclavos cuando, en su África natal, profesaban una determinada religión antes de ser capturados. Posiblemente Duque no estaba en condiciones de hacerlo, por desconocimiento de las religiones respectivas de cada una de las etnias que los esclavos representaban. Pero, en el supuesto de que pudiera haber tenido algún conocimiento de tales religiones o de alguna de sus prácticas o cultos, mencionarlo hubiera sido evocar un pasado pagano, que se oponía a la implantación del cristianismo. En la mentalidad de la época, la prevalencia de la religión cristiana frente a otras concepciones religiosas era tan evidente que no cabía hacer una oferta libre. Era un deber misionero, y a la vez, una consecuencia

61. Adición de Gabriel Menéndez de Luarca al catecismo de Astete, efectuada en 1787 (Ver L. Resines, Catecismos de Astete y Ripalda, Madrid, BAC, 1987, 118). 
civilizadora el llevar el cristianismo a quienes, bárbaros y rudos, lo desconocían. Era demasiado pronto para hablar de respeto religioso o de libertad de conciencia, y por tanto el cristianismo se presenta como la mejor y única posibilidad que los esclavos tenían, y que, por tanto, habían de aceptar.

Esta actitud de Duque (compartida entonces por todos) aparece perfectamente reflejada en las escasas palabras en que alude a África, con la referencia local a Guinea, como si todos los esclavos procedieran de allá, o porque era el trágico puerto de embarque y depósito de los negros que habían sido capturados en sus lugares de procedencia. Dice así:

«...no tengan el corazón duro, no fagan como gente que está en guinea, que no conoce a Dios, ni sabe que Dios manda. Ya Guinea se acabó, ya ustedes nunca volverán allá, ya son Christianos, ya son hijos de Dios, ya saben los mandamientos de la ley de dios, ya saben que los que guardan esos mandamientos van al cielo; y los que no los guardan van al infierno» 62 .

Hay una evocación de sus familiares y amigos que no han sido capturados (o de cuya captura posterior no son conocedores los esclavos transportados a Cuba), que permanecen en África (Guinea, según Duque, como referencia local). Éstos no han conocido a Dios, al Dios cristiano, mientras que los esclavos residentes en Cuba, sí le han conocido, bien que en unas duras condiciones, a su pesar. Laviña tiene razón al indicar que Duque "remarca la diferencia entre el esclavo cristianizado y el negro en África"63. Según la mentalidad de la época, los esclavos han tenido una oportunidad de salir de la barbarie y del paganismo en que estaban sumidos los habitantes de África, contemplados desde la perspectiva del supuestamente civilizado hombre europeo. Para él, los africanos residentes en sus tierras ancestrales eran dignos de compasión.

Es lógica, pues la invitación sincera de Duque a los esclavos a los que se dirige, para que aprovechen la oportunidad que conocer el cristianismo, de que hasta entonces habían carecido. Lo triste es que esta oportunidad no sea la de una oferta libre -como entendemos hoy- y que la ocasión de asumir el cristianismo fuese considerado como una "suerte" para los esclavos. Trágica "suerte" la de tener que aceptar una religión mal entendida, sin otra alternativa posible, y sin otra salida que la de plegarse (o aparentarlo, al menos) a lo que se les presentaba. A pesar de los esfuerzos valiosos de adaptación, una

62. Pg. 118-119.

63. Pg. 125. 
religión presentada desde los métodos coactivos de la esclavitud, incluso con el exquisito cuidado con que Duque habla de los esclavos, no podía producir más que una cristianización aparente y superficial. Pero entonces nadie estimaba que se pudiera proceder de otro modo.

Por otro lado, el horizonte cerrado que se presenta a los esclavos es tan desalentador como el mismo hecho de su condición infamante: «Ya Guinea se acabó, ya ustedes nunca volverán allá». ¡Perded toda esperanza! Pero, ¿les podía quedar alguna?, ¿tenían alguna remota posibilidad de intentarlo, al menos? Entiendo que Duque no trata de ser cruel ni añadir más sufrimientos, y se limita a la constatación de un hecho. Tampoco aparece alusión alguna a la otra posibilidad, más inmediata, de que algunos de los esclavos pudieran ser manumitidos, o compraran a sus amos su propia libertad con su esfuerzo y sus menguados ahorros. Los negros libres que vivían en Cuba eran manumitidos o descendientes de libertos. ¿Practicaban esos negros el cristianismo? Sin las presiones de la esclavitud, aunque con las presiones del control social, inevitable, ¿vivían la fe cristiana con sinceridad?, ¿por mera apariencia?, ¿rebrotaban los cultos africanos no extinguidos en su memoria ni en su corazón? Posiblemente de todo un poco. Pero ahí terminaban las aspiraciones de los negros. Impensable el retorno a su África natal. El cristianismo practicado como esclavos, o el cristianismo, asumido o no, como libertos era la única forma externa de religión en una época que no admitía ni veía que las cosas pudieran suceder de otra forma. Antonio Nicolás Duque se debe a esta época.

\section{ANÁLISIS DEL CATECISMO}

Tras haber contemplado algunos aspectos globales, más sobresalientes, es obligado hacer un examen de cada una de las partes que constituyen la obra de Duque de Estrada. Como cabía la posibilidad de hacerle con cualquier de los dos esquemas apuntados, me ha parecido más adecuado ceñirme al esquema real de la obra. Por tanto, le corresponde el turno en primer lugar al Catecismo.

Ya indiqué que ocupa las páginas 63-65, y que materialmente aparece sin título, aunque en dos momentos del resto del manuscrito, en llamadas internas, se refiere a esta parte con el nombre expreso de "Catecismo"64.

64. Pg. 67: «las preguntas y respuestas del catecismo que está al principio»; y 70: «...según el orden del catecismo que está al principio». 
No tiene nada de particular que Laviña no se haya parado en consideraciones catequéticas, que estaban fuera de su campo de acción, para presentar un catecismo. Está redactado en preguntas y respuestas, exclusivamente, hasta un total de 26, no numeradas. El conjunto es relativamente breve, como lo es también cada pregunta en particular. Para que se puedan hacer una idea quienes no tengan a la vista la reproducción del texto, las preguntas discurren por:

- Número de dioses (preg. 1)

- Dónde está Dios (preg. 2)

- Dios Creador (preg. 3)

- Trinidad (preg. 4-9)

- Encarnación de Jesús (preg. 10-13)

- Actuación de Jesús para salvar a los hombres (preg. 14)

- Muerte de Jesús en cuanto hombre (preg. 15)

- El alma humana es inmortal; el cuerpo es mortal (preg. 16-17)

- Suerte de los buenos y los malos (preg. 18-19)

- Iglesia (preg. 20)

- Presencia de Cristo en la eucaristía (preg. 21-22)

- Condiciones para comulgar (preg. 23)

- Condiciones para confesarse (preg. 24)

- Condiciones para salvarse (preg. 25)

- Qué son los sacramentos (preg. 26).

El lenguaje de estas preguntas es adecuado, con expresiones válidas (desde el punto de vista del lenguaje) y exactas (desde el punto de vista de la formulación de la fe); pero algunas de tales expresiones no se podían adecuar fácilmente a la mentalidad y cultura religiosa de los esclavos, como pueden ser «las obligaciones de nuestro estado» (preg. 25) o «morir en gracia» (preg. 26).

Semejante precisión y un esquema tan breve y tan perfilado me llevó a emprender la búsqueda de la fuente de que se había servido Antonio Nicolás Duque. Y, aunque aparecían similitudes con algunos otros catecismos, eran numerosas las diferencias. Todo esto hasta poder asegurar, sin el más mínimo temor a equivocación, que lo que hizo Duque en esta parte fue reproducir el catecismo breve, que provenía desde los primeros tiempos de la conquista española en América, atribuido a Pedro de Gante ${ }^{65}$, y posteriormente concre-

65. J. Cortés, El catecismo en pictogramas de Fray Pedro de Gante, Madrid, F.U.E., 1987, especialmente las pg. 267-316 y 442-443. L. Resines, Catecismos americanos del siglo XVI, Salamanca, Junta de Castilla y León, 1992, 120-125. 
tado en las expresiones más repetidas por Bartolomé Castaño. Lo único que hay de nuevo es que en la versión que reproduce Duque aparecen insertadas las preguntas $\mathrm{n}^{\circ} 22$ y 26 , que no aparecían con anterioridad en lo publicado con el nombre de Bartolomé Castaño.

Este texto, breve, sintético y claro, gozó de mucha popularidad y se extendió por todos los países cercanos al Caribe, perdurando por lo menos tres siglos. Y esta condición de resumen fundamental hizo que Duque, que lo conocía, no tuviera el más mínimo problema en incorporarlo a su obra. Si no señaló autoría fue, bien porque el mismo Duque ya no sabía quién era el autor, a base de utilizar el texto unos y otros evangelizadores; bien porque lo daba por supuesto, y estimó que nada cambiaba por citar o no el nombre de Bartolomé Castaño y el más antiguo aún de Pedro de Gante. Duque de Estrada, como tantos otros evangelizadores de diversos países de América estimó que, como punto de partida, este conjunto de 26 preguntas resumidas era más que suficiente para que lo aprendieran los esclavos negros; y, una vez aprendido, se pudiera llevar a cabo una explicación con mayor amplitud.

Es evidente que está destinado directamente a ser enseñado a los esclavos. Está redactado en el estilo culto y preciso de una adecuada expresión gramatical.

\section{ANÁLISIS DEL PRÓLOGO}

El "Prólogo" constituye una reflexión, en prosa, que ocupa las páginas 6670 en la edición comentada. La redacción reflexiva está destinada en esta ocasión a los capellanes, así como a otros posibles responsables de la educación cristiana de los esclavos. Una advertencia inicial, curiosa, indica: «Este prólogo debe leerse»; tal advertencia hace las veces de título, o si se prefiere, entresacando únicamente la palabra "Prólogo". La advertencia muestra la importancia que Duque asigna a su contenido. Éste se podría esquematizar de la siguiente forma:

- Advertencia inicial

- Condiciones propias de la enseñanza:

1. Entendimiento

2. Pronunciación

3. Corrección de errores

4. Referencia y uso del Catecismo

5. Empleo de los símiles 
- Condiciones externas a la enseñanza:

1. Circunspección y prudencia

2. El capellán, al margen de la marcha de la hacienda

3. Actuar como si no viere las cosas

4. No debe oponerse al castigo de los esclavos

5. Proceder cuando desconoce la causa del castigo

6. Prudencia en el trato con el mayoral

7. Ha de evitar disputas entre esclavos

8. No debe tener en la hacienda bienes propios

9. No debe apadrinar a los esclavos

10. Cuando le piden que interceda

11. No dar razón a los esclavos ante sus quejas

12. Mire el capellán a los esclavos con mucha caridad

13. Energía en la asistencia misa

-Notas finales.

La Advertencia inicial rechaza la suposición de la incapacidad de los esclavos para aprender la doctrina, y, al contrario, es una invitación a los capellanes para que hagan todos los esfuerzos por instruirlos, sin contentarse con un bautismo, aparentemente satisfactorio, pero que pone fin a toda instrucción cristiana. Añade una consideración sobre la pronunciación, repetida un poco más adelante.

Las condiciones de la enseñanza propiamente dicha hablan con claridad de la preocupación y de las dotes de observación y de rica experiencia acumulada por Duque. En el primer apartado se ocupa del entendimiento que han de adquirir los esclavos, como ideal de la enseñanza religiosa. No es suficiente con que sepan repetir.

En el segundo apartado se ocupa de la pronunciación. Ésta consigue sus resultados si los esclavos miran los labios del catequista, de manera que hable despacio, distinguiendo las sílabas. (Más adelante 66 añadirá que no es posible la enseñanza durante el tiempo en que ya ha obscurecido, porque los esclavos no ven los labios del catequista). Además, no debe decir algo nuevo hasta que no acaben de repetir; debe atajar el deseo de los negros de decirlo precipitadamente para acabar pronto; y debe acostumbrarles a esperar, sin prisas por terminar.

66. Pg. 73. 
Más aquilatado anda Duque cuando habla de la corrección de errores. Para ello recomienda que alguno, sin orden previo establecido, diga una oración: entonces se podrán corregir los defectos de la pronunciación mal aprendida; pero además, se podrán corregir los defectos de fondo, en cuanto a afirmaciones no exactas. Pone como ejemplo el de que no es lo mismo que digan «Nació Santa María Virgen», que «Nació de Santa María Virgen». Emplea el recurso de hacerles caer en la cuenta a los esclavos de que no es lo mismo decir "agua" que decir "yagua", aunque los sonidos se parezcan; no vale, pues, cualquier afirmación para expresar la fe, ni para entenderla bien, cuando se dice mal. En este punto, Duque recomienda que sea el propio capellán quien asuma la enseñanza religiosa, sin delegar en otro, sea blanco o negro, porque con frecuencia dicen disparates, por deseo de terminar pronto, o por imprecisión al no distinguir entre la verdad y el error. De ahí toma pie Laviña para deducir que la mente de Duque consistía en una profesionalización del capellán, con exclusión de otras personas, que hiciera imprescindible su papel.

El apartado siguiente es retroactivo, porque constituye una breve consideración sobre el Catecismo ya visto. Señala que las preguntas y respuestas deben preguntarse todos los días de misa, «uno a uno, otro a otro, indistintamente hasta el fin». En esas preguntas están contenidos los artículos necesarios con necesidad de medio, por lo que deben explicarse siempre con una explicación breve; el resto de las afirmaciones se podrán explicar poco a poco, según las disponibilidades de tiempo, o según la necesidad; por último, sugiere que el tiempo de la explicación no pase de media hora o tres cuartos de hora.

El apartado sobre los símiles ya ha sido contemplado, y omito repetirlo.

En cuanto a las condiciones externas a la enseñanza propiamente dicha, las trece que enumera Duque son una serie de consejos destinados al capellán. Varios de ellos se refieren al mayoral, como el personaje clave sobre el que giraba la marcha de la hacienda. Así recomienda circunspección y prudencia hacia él, pero sin familiaridad, de forma que el capellán aparezca como independiente a los ojos de los esclavos (condición $1^{\mathrm{a}}$ ); que no se oponga al castigo de los esclavos, y que debe limitarse a rogarlo, pero, en un consejo que rezuma experiencia, es preferible que deje al mayoral desahogarse un tanto (condición $4^{a}$ ); y si desconoce la causa del castigo, se limite a intervenir por señas, evitando ser visto por el esclavo castigado (condición $5^{\mathrm{a}}$ ); la prudencia con el mayoral tiene una explicación más amplia, porque -señala- son celosos de su autoridad y se molestan si algo se la disminuye; por tanto es preferible contar con él para la educación de los esclavos que enfrentarse con él, o dejarle a un lado, acudiendo al amo, lo que es moralmente imposible (condición $6^{a}$ ); que cuando haya disputas entre esclavos, el capellán se abstenga de 
intervenir, y que los envíe al mayoral, o al amo, como sus jueces naturales; 1o más que puede hacer el capellán es alguna sugerencia al mayoral (condición $7^{\mathrm{a}}$ ); que procure disculpar al mayoral ante las quejas de los esclavos, evitando minar su autoridad (condición $11^{\mathrm{a}}$ ).

Otras condiciones se refieren a que el capellán disponga de independencia económica y carezca de bienes e intereses en la hacienda, lo que es causa de conflicto y le resta libertad (condición $8^{\text {a }}$ ); que no apadrine a los esclavos, y mantenga una cierta distancia estratégica, y que, si se lo piden, es preferible hacerse de rogar; pero esa aparente frialdad está suficiente compensada con las afirmaciones de que "mire con mucha caridad por los esclavos", que no deje de "interceder por ellos" (condiciones $9^{a}, 10^{a}$ y $12^{a}$ ); y, finalmente, que sea enérgico con los esclavos en cuanto a exigir la asistencia a misa; esto tiene que hacerlo de tal manera que los negros lleguen a percibir que la actuación del capellán no busca beneficio para sí mismo, sino para ellos.

Por último, hay dos notas finales, que reflejan un deseo perfeccionista de Antonio Nicolás Duque: La primera insiste en que las explicaciones no resulten demasiado largas, porque pueden generar fastidio; y en la segunda advierte a los lectores (otros capellanes) que algunas cosas están en desorden, pero que remite al buen criterio de cada capellán el empleo en un orden u otro de los consejos que proporciona, destinados, intencionalmente, a que otros sacerdotes no pierdan el tiempo ni el trabajo, y se aprovechen de la experiencia recogida en estas páginas.

\section{ANÁLISIS DE LA INSTRUCCIÓN}

A continuación aparece la Instrucción, dotada del título completo: "Instrucción para los que se dedican a enseñar a rezar las oraciones y Catecismo". Ocupa las páginas 71-75. El título indica quiénes son los destinatarios de esta instrucción: los capellanes, y aquellos otros (expresamente cita a los amos) que se dedican a la enseñanza elemental: la de enseñar a rezar las oraciones, y el aprendizaje del Catecismo. El que otras personas diversas de los capellanes emprendieran esta labor supone una cierta contradicción con el principio que había establecido Duque de Estrada, en el sentido de que el capellán asumiera esta tarea por sí mismo, y no la delegara en otros, fueran blancos (se supone que más cultos) o negros (se supone que viejos esclavos cristianizados) puesto que unos u otros decían disparates, por querer terminar cuanto antes o por no diferenciar la verdad del error en una afirmación determinada. Lo cierto es que ahora aparecen otros catequistas, para los cuales está escrita la Instrucción. 
Su esquema es:

- Avisos sobre las principales afirmaciones de la fe (5 avisos)

- Observaciones prácticas

1. Enseñar poco a poco

2. Deletreo de las sílabas

3. Pronunciación adecuada de las palabras

- Recomendaciones finales.

Al examinar cada una de la partes encontramos, en primer lugar, unos avisos sobre las principales afirmaciones de la fe cristiana; aunque ha hablado en otro lugar con términos precisos, al dirigirse a los capellanes, empleando la expresión "cosas que deben saber con necesidad de medio" (suele expresar como "verdades necesarias con necesidad de medio"), cuando ahora se dirige a los amos y otros posibles catequistas, deja a un lado el tecnicismo, pero no así la importancia que tales afirmaciones revisten.

En efecto, ya he indicado que la exquisita concepción que Antonio Nicolás Duque tiene de los negros le lleva a lamentar la situación en que se encuentran inmensos, y le lleva a clamar con dolor: «i...pobrecitos...!». Tal exclamación, situada en el contexto de la frase, dice:

«Ruegos [=ruégoos] por las entrañas de nuestro señor Jesucristo y por el deseo que sentís de alcanzar misericordia, que la tengáis de estos pobrecitos (que muchos de ellos se condenan por falta de instrucción), para que nuestro Señor la tenga con vosotros según su divina palabra: Beati misericordes, quoniam ipsi misericordiam consequentur» 67.

De acuerdo con la reflexión teológica, estas verdades son absolutamente indispensables para la salvación; de ahí que la lamentación de Duque no abarque solo su vergonzosa situación presente, sino también la posibilidad de futura condenación68. La misma preocupación consta al comienzo de la Instrucción:

67. Pg. 120.

68. Otra cosa diversa son las posibilidades reales que cada hombre, en su tiempo o cultura, ha tenido a su alcance, para llegar a conocer explícitamente y hacer suyas cada unas de estas afirmaciones. Pero estos matices no aparecen en las afirmaciones de Duque. 
«Lo que deben saber y entender los que tienen uso de razón para salvarse, de suerte que si no lo saben y no lo entienden de la manera que mejor pueden no se salvarán, aunque no sea culpable su ignorancia» 69 .

Tales verdades necesarias, que centran la preocupación de Duque son:

1. Existencia de un solo Dios,

2. En Dios hay tres personas

3. Dios es el creador de todo

4. La segunda persona, el Hijo, se hizo hombre

5. Los buenos cristianos van al cielo y los malos al infierno ${ }^{70}$.

Junto con las afirmaciones $3^{\mathrm{a}}$ y $4^{\mathrm{a}}$, aparecen sendas adaptaciones de orden pedagógico. La primera, a propósito de Dios creador, dice: «En cada una de estas cosas puede extenderse el que enseña a referir por menudo lo que le parezca conveniente para que comprehendan estas verdades». La segunda, sobre la encarnación de Jesús, explica que «tomó la naturaleza humana» y aclara el concepto como «se juntó con un cuerpo y una alma de hombre». Es patente que Duque no desea ceñirse a la pura repetición material, y apunta a la comprensión de lo afirmado, de manera que pueda llegar a ser percibido por los esclavos.

Una vez enunciadas estas verdades, vuelve a aparecer la preocupación de Duque, puesto que no es suficiente con que digan los esclavos estas afirmaciones, sino que las entiendan, para asegurar su salvación. Se superponen la preocupación de su mentalidad rigorista, con el interés catequético de no conformarse con la mera repetición mecánica. E incluso por tercera vez seguida

69. Pg. 71. El rigorismo de Duque es excesivo, puesto que la consideración más equilibrada indica la necesidad de conocer estas afirmaciones con dos matizaciones notables: $1^{\mathrm{a}}$ son necesarias para la salvación de aquellos que han tenido oportunidad de conocerlas, y por tanto han podido aceptarlas o rechazarlas; $2^{\mathrm{a}}$ no son necesarias en caso de ignorancia invencible, bien por limitaciones de la persona (p. ej., incapacidad), bien por las limitaciones del ambiente (p. ej., las religiones politeístas).

70. La mentalidad marxista de Laviña, sugiriendo que Duque se limitaba a presentar una salvación para el más allá, no casa demasiado bien con las frases con que Duque se expresa aquí, pues no habla de una salvación entrevista o soñada que les permite soportar sus penalidades, sino del concepto más equilibrado de que Dios establece la salvación para los buenos y la condenación para los malos. Y esto sin diferencias, aunque los buenos «sean negros, esclavos, pobres, aunque tengan llagas, calentura u otra enfermedad»; y aunque los malos sean «blancos, libres, ricos, caballeros, aunque no tengan enfermedad alguna». Es una forma, inteligible para los esclavos, de hablar de un Dios justo, que no realiza discriminaciones. 
surge esta preocupación en una advertencia dirigida expresamente a los amos, donde les recuerda la «gravísima obligación que tienen de instruir a sus esclavos (y lo mismo es de los demás domésticos)» para que no se contenten con enseñarles a repetir «como cotorras», y que «si tienen zelo christiano de la salvación de los esclavos, y de la suya propia... pidan a Dios... la gracia para explicarse y a los esclavos para que comprehendan la explicación»71. Al final de la Instrucción volverá a dirigirse a los amos con la misma idea de que no es suficiente la repetición, para lo cual deben recordar a menudo lo aprendido para que no se olvide 72

A los avisos sobre las principales verdades de la fe, siguen tres observaciones prácticas. Están situadas en este punto de la Instrucción, como podrían haber estado en el Prólogo; y se destinan a los amos y otras personas que enseñan, como podían haber sido destinadas a los capellanes (destinatarios directos del Prólogo). La repetición de algunas observaciones destacadas denotan el interés de Duque de Estrada, al dirigirse a amos o a capellanes con el mismo convencimiento de lo que resulta útil en la enseñanza cristiana.

La primera observación se refiere a que en la enseñanza de los negros ha de procederse poco a poco, como se llena poco a poco un frasco o botella de cuello estrecho, y no se echa el agua de golpe; además da una razón que va más allá de la simple comparación: «consideren que la capacidad de los negros (especialmente por la falta de inteligencia de nuestra lengua) es mui corta». No es ociosa esta constatación, y no es posible obviarla, por el deseo inadecuado de conseguir una educación cristiana rápida, pasando por alto las enormes dificultades de comprensión. $\mathrm{Ni}$ que decir tiene las dificultades que hubieran encontrados los amos y capellanes si hubieran querido adaptarse a los esclavos, enseñándoles en sus respectivas lenguas. Pero son los esclavos quienes han de adaptarse a la lengua de los amos, que comprenden mal y en la que no se expresan más que deficientemente. La paciencia requerida es, por tanto, obligada.

La segunda observación, reiterada, es que se proceda deletreando las palabras; para ello aconseja que los esclavos miren a los labios de quien les enseña; en consecuencia, no es posible hacer la explicación de la doctrina de noche, porque no pueden seguir el movimiento de los labios; para esta labor de aprender las oraciones bastará con un cuarto de hora para que no se can- 
sen ni catequistas ni catequizandos. Pone como ejemplo la enseñanza del padrenuestro, procediendo frase a frase, y recomendando que cada vez que, en el transcurso de la jornada, se encuentren amo y esclavo, aquél le pregunte la frase aprendida y se la haga repetir, para que la constancia produzca su efecto. Termina diciendo que se necesita más arte que fuerza para que aprendan de memoria.

La tercera observación se refiere no tanto a la repetición y pronunciación, sino al sentido de lo aprendido, de manera que no separen las palabras y éstas carezcan de sentido. Duque afirma que «más parece que se les enseña a pregonar que a rezar», con unas oraciones que son una retahíla de palabras inconexas, a lo que no se puede llamar oración. Termina esta observación con una reflexión pedagógica muy bien aducida, al asegurar que cuesta lo mismo enseñar bien que enseñar mal, y por tanto vale la pena poner los medios para no gastar energías inútiles en el intento.

Las recomendaciones finales constituyen un ir y venir entre afirmaciones dichas y repetidas, pero no están exentas de algunos matices interesantes. La primera recomendación se detiene en el defecto de la simplificación del castellano por parte de los esclavos, ante la premura del aprendizaje, y por un mecanismo de elegir la vía más sencilla. De esta forma, Duque constata que suelen quitar una o dos sílabas a cada palabra, con lo cual el conjunto de una frase sufre una transformación notable:

De «Padre nuestro que estás en los cielos»

sale « $\mathrm{Pa}$ - nue-tro - - tas-en-o cielo» en labios de los esclavos. Por tanto, si saben más palabras sueltas, más sílabas omiten, y en realidad saben menos.

En consecuencia surge la segunda recomendación: cuesta quitarles el defecto, pero hay que intentar que no digan palabras o sílabas separadas, sino que del silabeo inicial pasen a la fusión adecuada de las palabras y de las frases.

La tercera recomendación, ya casi dicha, es que hay que enseñarlos con paciencia, y no con golpes. Pero la novedad de esta recomendación consiste en añadir una lúcida frase: si no se lleva a cabo la enseñanza como ha dicho, el tiempo de instrucción se convierte para los esclavos en tiempo de tormento, que conseguirá «que tenga más cuidado con el látigo que con la doctrina» ${ }^{73}$. Y una doctrina cristiana inculcada a latigazos es lo más distante de lo que Duque propone.

La recomendación cuarta casi estaba enunciada ya, al indicar que el esclavo tiene que percibir con la instrucción religiosa que esto no se lleva a cabo en interés del amo, sino por el bien propio del esclavo, para que sea buen cris- 
tiano. No siempre resultaba tarea fácil que llegaran a semejante percepción, porque con frecuencia no sentían necesidad alguna de una nueva religión, y los mecanismos de enseñanza eran entendidos como una imposición más de parte de los amos, y no como una elección libre y voluntaria de los esclavos. Por último, la quinta y última recomendación, repetida en varias ocasiones, consiste en recordar la insuficiencia de un aprendizaje de memoria, y para evitarlo, los amos deben aprovechar todas las oportunidades de contacto con los esclavos para recordarles la doctrina aprendida.

\section{ANÁLISIS DE LA EXPLICACIÓN DE LA DOCTRINA CRISTIANA...}

En el orden establecido por Duque, con el que aparece la transcripción de la obra, sigue la Explicación de la doctrina cristiana acomodada a la capacidad de los nogros bozales ${ }^{74}$. Ocupa desde la página 77 hasta la página 103. Es, por tanto, una parte extensa, en la que Duque lleva a cabo una explicación detenida. Aunque en ningún sitio lo diga de forma expresa, la Explicación remite a las 26 preguntas básicas que habían aparecido en el Catecismo, por lo cual, parece lógico pensar que ambas partes -texto básico y explicación complementaria- deberían ir una a continuación de la otra.

Sin embargo, las 26 preguntas básicas son complementadas y explicadas con muchas más preguntas, hasta un total de 91 , lo que supone la adición de 65 preguntas más; a cada pregunta del Catecismo sigue una, o, más frecuentemente, bastantes preguntas, en número desigual, para explicar cada uno de los apartados. Sin embargo, algunas de las preguntas originales del Catecismo (preg. $\mathrm{n}^{\circ} 1,4,6,7,8,15,18$ ) carecen de otras que las complementen y aparecen solas, como en la redacción a la que remiten.

Duque realiza la explicación por medio de otras preguntas añadidas, aunque en ocasiones algunas de las respuestas sean tan extensas que, en realidad, se trata del método expositivo, en lugar del interrogativo; al principio de la Explicación las respuestas son más breves, y a medida que avanza se tornan

73. Pg. 75 .

74. Ya he indicado que el libro, tal como está editado, incluye (pg. 61) una reproducción facsímil de una página (acaso la del comienzo, pues el editor la sitúa precisamente ahí), cuyo texto dice: «Explicación de la doctrina cristiana acomodada a la capacidad de los negros bozales. Contiene todo lo que debe saberse así con necesidad de medio como con necesidad de precepto. Por un sacerdote de la Congregación del Oratorio de la Habana». Como puede comprobarse, la primera frase coincide con el título de la parte que voy a analizar, pero las dos frases siguientes no aparecen transcritas en ningún lugar de la obra. 
en respuestas extensas. Es claro que mientras las preguntas-respuestas breves podrían ser aprendidas de memoria, esto no es posible con las más largas.

Esta amplia Explicación está destinada a los propios negros, a cuya capacidad limitada intenta acomodarse. Por lo tanto está redactada siguiendo las pautas del lenguaje entrecortado, repetitivo y de construcción deficiente que los esclavos utilizaban, para adecuarse mejor a lo que puedan entender por medio del modismo que han aprendido y emplean. El empleo de símiles y comparaciones resultan muy abundante.

Como resulta imposible reproducir o comentar una por una cada una de ellas, lo procedente será fijar la atención en aquello que resulte más sobresaliente. En relación a los atributos de Dios, señala que, aunque está en todas partes, no le hemos visto, y sabemos de su presencia porque Él mismo lo ha dicho y no es mentiroso. Además indica que es creador, partiendo de la nada, a diferencia de los artífices humanos; y que es todopoderoso, porque le basta ordenar las cosas; en este punto establece el contraste (que no comparación) entre el trabajo que les cuesta a los amos obtener el azúcar a partir de la caña, mientras que a Dios no le cuesta trabajo alguno hacer las coas.

Otro apartado se centra en la Trinidad, con las diferencias entre personas, y la afirmación de que no se trata de tres dioses sino de un único Dios con las comparaciones de los tres huesos de un solo dedo, las tres partes de un solo huevo, o las de una sola naranja, aguacate o melón; finalmente enseña que ninguna de las tres personas sabe más, puede más o es más viejo.

Siguen las preguntas sobre la encarnación, con la afirmación de que sólo Jesús se encarnó; que era verdadero Dios y hombre, y no un dios pintado, o de palo o barro, sino vivo. Hace una referencia a "esto", que por el contexto se deduce que es el crucifijo, que es la representación pintada; pero Jesús se hizo hombre real. Para explicar que «tomó la naturaleza humana», explica que cada animal tiene su naturaleza y pertenece a su especie (su "cuadrilla"). Jesús se hizo hombre en el vientre (lo señala como equivalente de "barriga", "entrañas") de María, pero no es hijo de hombre y mujer, sino de mujer sola, lo que es un milagro de Dios. Enseña, como hacía la teología de la época, la la formación instantánea el cuerpo total y perfecto, a diferencia del resto de los humanos ${ }^{75}$. Enseña que María parió sin dolores, quedando doncella, para significar así su virginidad. Y para transmitir el concepto de que es Madre de

75. También enseña, según los patrones de la época, que el cuerpo del varón se tarda en formar 40 días, mientras que el la hembra tarda 80 días. Semejante concepción era admitida sin discusión por todos. 
Dios, se sirve de esta expresión: «La que pare perro es madre perro; la que pare gato es madre gato; la que pare hombre es madre hombre; la que pare Dios es madre Dios»76. Acomodándose al mundo reducido de los esclavos, asegura que María es madre verdadera a diferencia de la madrina, la madrastra o la criandera (=nodriza), que no lo son.

Jesús murió por salvar a los pecadores. Esta idea la explica sirviéndose de la referencia a las tareas diversas de la hacienda, designadas cada una por una palabra diversa. Si el chapeador es el que chapea, pecador es el que hace pecados. Y todos los hombres estamos en esa situación. De Adán, como origen de los pecados, afirma que hizo penitencia durante 900 años ${ }^{77}$. Al hablar de la Pasión dice que Jesús fue castigado por orden de Pilato, como el esclavo es castigado por orden del amo. Duque comenta la afirmación del descenso a los infiernos en el sentido más tradicional, con la expresión de «Limbo de los Santos Padres». Cuando describe los tradicionales "cuatro infiernos", hace una descripción muy vívida, y casi sensible, que sería bien percibida por los esclavos, y que no se aparta demasiado de la concepción (otra cosa son las expresiones) común en los catecismos de la época.

Cuando aborda la resurrección, Duque anotó al margen del escrito una precisión de índole pedagógica, que repetirá más adelante, en el sentido de que la explicación se anime y acompañe con la acción del capellán, para que el gesto acompañe a la voz y pueda ser mejor asimilado78. Al afirmar que subió al cielo dice que no lo hizo sirviéndose de una escalera, ni como se sube a una palma o se trepa a un palo. Cuando afirma que Jesús vendrá a juzgar a los hombres, se sirve de la comparación del mayoral, que pide cuentas a los esclavos de la tarea que les ha asignado. Pero hay otra afirmación, extraordinariamente importante, para justificar que Jesús tiene motivo para pedirnos cuentas, y es que «desde que nacemos, desde que nos parió nuestra madre, somos esclavos de Dios». Hoy no sería posible suscribir semejante afirmación para describir la vida cristiana, de la que Dios es Señor y Juez; pero es comprensible que en el reducido esquema de los esclavos, fuera la mejor forma de hacerse entender, o acaso la única forma posible ${ }^{79}$.

76. Pg. 83.

77. Se refiere al texto bíblico de Gn. 5, 5 que habla de la longevidad de Adán, pero nada dice sobre esa vida de penitencia.

78. Pg. 87; en pg. 93 dice: «Haga la figura con las manos para que entiendan», y «Vuelvo a decir que todo esto pide ser acompañado con la acción, que es lo que esclarece a quien casi no tiene noticia del idioma, como son los negros».

79. Entiendo, simplemente, que es una forma amañada la empleada por Laviña, retorciendo las afirmaciones para asegurar que Duque «establece comparaciones entre Dios y el amo» (pg. 125) para buscar con ello el sometimiento de los esclavos. 
Otras preguntas hablan de que el hombre es mortal en cuanto al cuerpo, pero no en cuanto al alma, a diferencia de los animales. Esa supervivencia apunta a la resurrección final. E incluye una precisión, cual es que cuando se refiere a los "hombres" incluye también a las mujeres, pero para darle más fuerza, por razón de la pertenencia a la especie humana, emplea una frase que hoy no sería suscrita por nadie que disponga de una antropología elemental: «Es menester que sepan ustedes que quando se fabla de hombre se entienden también las mugeres, porque las mugeres son hombres fembra, y los hombres, hombres varón».

Presenta la suerte de las personas como una situación eterna («durarán para siempre, nunca se acabarán») en el cielo o en el infierno ${ }^{80}$, según estén en gracia o en pecado. Esto le obliga a hablar de los pecados mortales («que son los pecados grandes») y de «los chicos, que son los que se llaman veniales», que merecen menos castigo: el purgatorio. Allí es «donde se paga todo lo que falta por pagar por los pecados». Y compara la suerte de las personas juzgadas por Dios con algo bien conocido por los negros:

«Esto es como el azúcar: la azúcar que sale quemada, esa va a las canoas o al estanque de la miel, porque no sirve más que para facer aguaardiente (sic). La azúcar que sale buena va a la casa de la purga, porque es menester que se ponga blanca, y allí está hasta que se pone blanca, bien purgada. Esto ustedes lo saben»81.

Se ocupa de la Iglesia con relativa brevedad, y la comparación de los dedos y la mano le sirve para hablar de la unidad de la Iglesia. El puesto central le corresponde a Cristo y en su lugar gobierna el papa, de la misma manera que en la hacienda el amo delega funciones de gobierno en el mayoral.

Sigue con las nociones sobre la eucaristía, en un tratado que no difiere en el fondo de los tratados de otros catecismos, pero que se acomoda al habla de los negros para explicar nociones como transubstanciación, substancia o accidentes, que sería muy difíciles de captar. Explica la presencia de Cristo en la eucaristía y la recepción completa para quien comulga aunque reciba sólo una parte de la forma. Hay una indicación de orden, a la vez que una llamada a lạ prudencia de otros evangelizadores, a continuación de hablar que el pan y vino consagrados se llaman sacramento del Altar, pues añade: «Aquí sigue la

80. Será preciso volver más adelante sobre el tema.

81. Pg. 92. También en este punto, tan próximo a la comprensión de los esclavos, y tan adecuadamente expresado, ironiza Laviña al afirmar (pg. 125) que «la comparación entre el purgatorio y la casa de la purga» era un medio para conseguir el sometimiento del esclavo al sistema establecido. 
explicación que tiene esta marca * si pareciere conveniente»82. Creo que es preciso destacar el estilo de Duque de Estrada, al señalar que otros evangelizadores puedan, a su respectivo criterio, utilizar lo que estimen conveniente para la explicación.

La cuestión de las condiciones que se deben reunir para recibir la eucaristía empalma con el amplio apartado que dedica a la penitencia (páginas 94 a 101): todo esto es la dilatada explicación que corresponde a una sola pregunta (la $\left.\mathrm{n}^{\circ} 24\right)$ del Catecismo básico utilizado. Al comienzo de lo relativo a la penitencia indica que «hay mucho que saber», o, lo que es lo mismo, que es algo muy importante. Inserta la explicación de la penitencia en el contexto de los sacramentos (curiosamente no había hecho lo mismo con la eucaristía), y de los sacramentos en general afirma que son «remedios para curar los pecados que enferman el alma». Y ofrece una definición (?) de penitencia que corre el riesgo de ser entendida de forma completamente material: «es un remedio que fizo Nuestro Señor Jesucristo de su misma sangre para curar el alma de los pecados». Esta definición se inserta en la concepción, que repetirá más adelante ${ }^{83}$, según la cual los sacramentos son remedios, como equivalentes a medicinas, y son comparados con las medicinas o boticas que receta el médico.

Duque prosigue presentando lo relativo a la penitencia, y lo hace con el trasfondo expresamente abordado de que la confesión consiste en ajustar cuentas con Dios, como se ajustan cuentas pendientes de lo que se debe en la taberna. Habla de dos clases de confesión: una para castigar, obtenida empleando la fuerza con el esclavo que ha delinquido; otra para perdonar, que surge espontáneamente por el sentimiento de culpa, y ante ella el amo o el mayoral perdonan. Ésta es la que le sirve para hablar de la penitencia, presentando el amor misericordioso de Dios: «Dios nos quiere más que nuestro padre y nuestra madre, ¿cómo puede tener el corazón duro quando está mirando al que se confiesa, que le fabla verdad, que lo mismo que dice su boca eso mismo dice su corazón?».

Describe el pecado como dar una bofetada a Dios en la cara, recordando lo que ya había dicho al hablar antes del pecado mortal84; como consecuencia

82. Pg. 93. Se produce aquí un hecho desconcertante en esta llamada, porque lo que tendría que tener empalme lógico más adelante (pg. 114-115), al volver sobre el tema de la eucaristía, aparece en la transcripción sin asterisco que corresponda a la llamada; y, por el contrario, aparece un asterisco en la pg. 113 («véase el párrafo que tiene esta señal»), pero en ese lugar está tratando del bautismo, por lo que parece que no ha de remitirse a tal lugar.

83. Pg. 102 .

84. Pg. 91. 
«Dios está bravo con nosotros», pero cuando ve que el pecador se duele no espera a otro día para perdonar. Con relación al dolor de los pecados, aclara que no se trata de un dolor físico, y lo compara al dolor que produce la pérdida de un dinero confiado a otro85. Habla también del propósito que ha de ser firme, como firme ha de ser el "forcón" o soporte central en torno al cual el esclavo construía su choza o bujío. Y alude, casi de pasada, a los enemigos del hombre que le incitan a pecar; pero en lugar de denominarlos con la expresión convencional de demonio, mundo y carne, emplea la de «diablo, gente mala y nuestro mismo cuerpo- ${ }^{86}$. Las últimas cuestiones sobre la penitencia se centran en huir de las ocasiones de pecado y no volver a caer en ellas; pone el ejemplo de quien se atasca con una yegua o un caballo en un barrizal, que debe evitarlo en otras ocasiones, y añade que es preciso querer más al alma que a la yegua o al caballo.

Los comentarios de Duque de Estrada a las dos últimas preguntas del Catecismo se centran en hablar de la salvación, que consiste en ir a la casa de Dios. Con una frase colorista, doméstica y muy acorde con las limitaciones impuestas a los esclavos, Duque afirma que el cielo consiste en ir a la casa de Dios, pero no a la cocina, sino a la sala, y cenar en la mesa de Dios y de la Virgen; el cielo también consiste en descansar para siempre, lo que no era mala referencia para los esclavos, obligados a un trabajo sin reglamentación alguna. Por último denomina al cielo como nuestra propia casa, puesto que la casa del Padre (Dios) es también la casa de los hijos.

La última pregunta se ciñe a repetir en forma breve lo que ya había dicho de los sacramentos, como remedios hechos con la misma sangre de Cristo ${ }^{87}$. Y termina con una nueva llamada de atención a la recortada capacidad de los esclavos por el conocimiento limitado del idioma en que se les habla:

«Me parece que bastará que conciban que los sacramentos son para el alma lo que los medicamentos para el cuerpo, porque para su capacidad y falta de inteligencia del castellano es demasiada carga más larga explicación».

85. Pg. 99-100. Se deduce, pues, que los negros manejaban alguna cantidad de dinero, con la que atendían a sus propias necesidades, o como ayuda a su subsistencia (deudas en la taberna), así como también con la que adquirían la manumisión.

86. Pg. 100; también en pg. 108 y 115.

87. Tanto en ésta como en la pregunta anterior, Duque de Estrada hace una cita interna a su propia obra, remitiendo a explicaciones que ha proporcionado en páginas anteriores, para evitar su repetición. 
Como ha podido comprobarse en esta visión panorámica de la Explicación, ésta es amplia, extensa, y en general bastante completa, aunque no pretenda una explicación total de la fe. Puesto que tanto el Catecismo como la Explicación están destinados directamente a los esclavos, es posible hablar, sin miedo a errar, de un doble nivel catequético previsto en el escrito de Antonio Nicolás Duque: un primer nivel, elemental, básico, constituido por el Catecismo en la redacción de Bartolomé Castaño, y que, con retoques, llegó hasta él, y lo presenta como la primera síntesis cristiana para los esclavos; y una segunda síntesis, más amplia y razonada, que constituiría el nivel superior, para los esclavos que hubieran superado la primera etapa y estuvieran en condiciones de un mejor conocimiento en la Explicación ${ }^{88}$. Y aunque el título de la misma habla de los negros "bozales", es decir, los recién arrancados de sus tierras, lo cierto es que el tono de la Explicación remite con nitidez a negros que ya llevaban un largo tiempo en Cuba, que habían conocido unas primeras nociones de la fe cristiana con anterioridad. El mismo hecho de proporcionar una más completa presentación de la fe denota el talante ilustrado de Antonio Nicolás Duque.

\section{ANÁLISIS DE LOS TRATADOS FINALES}

En la reproducción ya mencionada, al término de la Explicación siguen otros apartados, cada uno de los cuales está dotado de su titulillo correspondiente. Cabría entenderlos como continuación de la Explicación, o como distintos de ella. Me he inclinado por la segunda posibilidad, puesto que cambia también el estilo de lo escrito. En efecto, la Explicación se dirigía a los negros y estaba redactada con el estilo entrecortado y con deficiente sintaxis, propia de la jerga de los esclavos; ahora se dirige de nuevo a los catequistas, en algunos momentos, aunque en otras ocasiones mezcle párrafos (o todo un apartado) en la lengua castellana que los esclavos utilizaban; por otra parte, se da alguna repetición, como muestra de que lo que presenta en estos tratados finales es cosa diversa y complementaria de lo anteriormente redactado. Ya indiqué, además, que son reflexiones expositivas, y que cada una de ellas goza de una cierta autonomía, pues no se refiere a una pregunta concreta de la Explicación.

88. Aquilatando todavía más, se encuentra otro nivel previo al del Catecismo, que aparece en la Instrucción, y que consiste en las cinco afirmaciones necesarias para salvarse (necesidad de medio); de ahí se pasaría al Catecismo y, finalmente, a la Explicación. 
Los que he incluído en esta denominación genérica de "tratados" finales son:

- Para que sepan que deben saber y entender la doctrina christiana (pág. 103-109)

- Para que hagan sus obras con provecho (pág. 109-111)

- Sobre el Padrenuestro (pág. 111)

- [Sobre el] Ave María y Salve Regina (pág. 112)

- Sobre el baptismo (sic) (pág. 112-114)

- Sobre la eucharistía (sic) (pág. 114-115)

- Sobre los mandamientos (pág. 115-120)

- [Recomendación final a los capellanes] (pág. 120).

Siete apartados, o "tratados", centrados cada uno de ellos en un tema particular, y, como puede apreciarse por el número de páginas que ocupan, con desigual extensión. La diferencia de temas abordados obliga a analizarlos cada uno por separado, ya que tampoco constituyen en conjunto un escrito catequético completo.

A) Para que sepan que deben saber y entender la doctrina christiana. Insiste en nociones ya repetidas: la importancia de conocer la doctrina cristiana para llevarla a la práctica; saber se llama entender y no sólo repetir. Hay que insistir a los esclavos para que pongan cuidado (no dormirse, ni mirar para otro lado, sino a la cara del sacerdote que les enseña). Y proporciona como novedad tres razones para dar a entender la importancia de la doctrina cristiana; $1^{\mathrm{a}}$ ) es la doctrina que enseñó Jesucristo; $2^{\mathrm{a}}$ ) sirve para el alma como el alimento para el cuerpo, pues es la palabra de Dios; y $3^{\mathrm{a}}$ ) no sirve sólo para el provecho del amo, sino para el bien del propio esclavo.

Recuerda (a los capellanes y catequistas a quienes se dirige en este tratado) que el amo tiene obligación de enseñar, y que los esclavos tienen obligación de aprender. Por consiguiente, si el esclavo no quiere aprender cuando se le enseña, a nadie puede hacer responsable de su ignorancia más que a sí mismo. Por el contrario, los que tienen voluntad de aprender han de procurar mantener lo aprendido en el corazón, y no sólo en la memoria. Y proporciona unos consejos prácticos: - para no olvidar lo aprendido es bueno hablarlo con los demás; - si en el curso de la conversación disputan sobre lo que les han enseñado, acudan al sacerdote, que se lo aclarará; - para no olvidar lo aprendido es bueno pensar en ello.

Lo anterior se refería, en general, a la doctrina cristiana. Pero dentro del mismo apartado, y sin interrupción alguna, salta al tema de la penitencia por medio de tres consejos a los catequistas: - en necesario enseñarles a formar 
contrición; - convendrá que les tomen de memoria el acto de contrición; -y para aprenderlo recomienda concluir con él cada rato dedicado a la doctrina cristiana.

Nuevo salto dentro del mismo apartado, abordando la cuestión de la escasa asistencia a misa por parte de los negros ${ }^{89}$. Para evitarlo ofrecer seis razones para conducirlos a misa:

1) La misa es cosa buena ante Dios; y Dios es nuestro amo.

2) Todo nos lo ha dado; debemos agradecérselo.

3) La misa sirve para pagar lo que debemos en el purgatorio.

4) No podemos hacer nada por nuestra cuenta para ir al cielo; debemos pedírselo a Dios.

5) Debemos pedir ayuda a Dios ante la tentación y ante nuestros enemigos

6) El hombre es pecador; le pide a Dios que le libre de una mala muerte.

Además de estas razones, Duque argumenta que muchos pierden la misa porque anteponen a ella otros trabajos y ocupaciones, la mayor parte de las cuales sirven para el bienestar corporal; pero recuerda que, a la muerte, el cuerpo se queda en tierra y el alma es la que va ante Dios con lo que haya hecho para cumplir sus deseos.

B) Para que hagan sus obras con provecho. En este caso el "tratado" completo está dirigido a los esclavos y no a los catequistas. Señala que es propio de los cristianos hacer las cosas con ganas de servir a Dios; y no hacerlas como una mula, que no sabe lo que hace. De ahí que el comer se realice porque Dios quiere que mantengamos la vida del cuerpo; el trabajar, porque Dios quiere que sirva al amo; el dormir, porque Dios quiere que descanse; y así se podría seguir por todo lo que es posible hacer y que no constituye pecado. Todo lo que hace un cristiano debe ser con ganas de servir a Dios, aunque sea poca cosa. En este punto, Duque de Estrada se lamenta de la situación de los esclavos, que están trabajando sin parar. Y aconseja que el trabajo han de hacerlo para servir a Dios.

89. Esto denota una cierta libertad de movimientos de los esclavos dentro de las plantaciones; así como una cierta capacidad de disponer de su tiempo, al menos en algunas ocasiones. Laviña refleja que con el auge de la explotación del azúcar, se restringieron sus movimientos, su tiempo libre, y se forzó su trabajo para obtener alta rentabilidad en poco tiempo. Es muy posible que Duque se esté refiriendo a la situación anterior. 
C) Sobre el Padrenuestro. Apartado breve, sin duda. Remite a la enseñanza de Jesús a sus discípulos. Incluye la escueta recomendación que dice: «Dígase todo», que evidentemente se refiere a todo el texto de la oración; por cierto no aparece expresamente en el escrito de Duque, como tampoco ningún otro formulario, porque supone su conocimiento por parte de los capellanes, y porque sería innecesario escribirlo para ellos; y a los esclavos no les iba a llegar un texto, manuscrito o impreso, que no eran capaces de descifrar.

Enseña que Dios dará todo lo que se le pide, con tal que no sean cosas malas. Que es preciso rezar el padrenuestro para ser un buen cristiano, para ayudar a hacer una buena confesión, para pedir una buena muerte, para pedir a Dios lo necesario: variadas ocasiones que invitan a que los esclavos supiesen la oración y la utilizaran con asiduidad.

Parece desprenderse del análisis de la redacción que indirectamente se dirige a los negros, aunque lo haga a través de los capellanes, que podrían servirse del texto escrito por Duque. Lo mismo sucede en el "tratado" siguiente.

D) [Sobre el] Ave María y Salve Regina. Igualmente breve el apartado que nos ocupa. Duque enseña que con estas oraciones hablamos con la Virgen, nuestra señora, madre de Jesucristo. Invita a emplear estas oraciones como un saludo, de la misma manera que los esclavos saludan respetuosamente a sus amos. Y se produce aquí una afirmación chocante, al decir que la Virgen es nuestra ama: es comprensible su uso, dada la carencia lingüística de los esclavos; pero desconcierta el empleo de la misma expresión para Dios y para la Virgen, con lo que se produciría la simplificación de atribuir a María categoría divina, en una identificación casi inevitable.

En cierto modo Duque trata de conjurar el peligro anterior, al afirmar que pedimos a María que sea nuestra madrina ${ }^{90}$, asegurando que ella hablará a Dios en favor nuestro. Por eso es bueno rezar la Salve.

E) Sobre el Baptismo. Es patente la falta de orden, tanto en el conjunto del escrito de Duque como en estos tratados finales, porque lo lógico hubiera

90. El concepto "padrino" o "madrina" ha salido en el escrito de Duque en varias ocasiones. Así, recomienda que el capellán no sea padrino de los esclavos, aunque no deje jamás de interceder por ellos; también aparece la idea de que María es la madre de Jesús, y no es madastra ni madrina, que no son propiamente madres; que el esclavo no se confíe demasiado a su madrina, pues le puede consumir el dinero que pone en sus manos (símil a propósito del dolor de los pecados); o que puede encontrar ocasiones de pecado cuando acude a visitar a su madrina. Ahora sublima el concepto, para remontarse a hablar de María como "madrina" ante Dios. 
sido encontrar primero lo relativo a los sacramentos, y después lo que trata del bautismo o los otros sacramentos; pero no es así. En las partes anteriores (Catecismo, Instrucción o Explicación) apenas se refiere al bautismo en algo que sobrepase una alusión o una línea suelta, aunque esté bien situada en el contexto correspondiente. Ahora le dedica algo más de atención.

La redacción muestra con claridad que todo lo que constituye este "tratado" está dirigido directamente a los esclavos, empleando con habilidad su estilo de expresión. Consecuente con su enseñanza sobre los sacramentos, el bautismo también es un remedio hecho con la misma sangre de Cristo ${ }^{91}$. Hace una referencia interna a su propio texto para recordar lo dicho sobre el pecado original, de forma que todos nacemos pecadores ${ }^{22}$. El bautismo quita los pecados, y, con una frase sorprendente, aunque acomodada a la percepción de los destinatarios, dejamos de ser esclavos del diablo para pasar a ser hijos de Dios $^{93}$. Las consecuencias, después de recibir el bautismo, son: debemos evitar el pecado, debemos hacer propósito firme de evitar las ocasiones de cometerlos, debemos guardar los mandamientos, y debemos tener disposición para recibir el resto de los sacramentos.

Este sería el plan ideal de la vida cristiana. Pero, con sentido realista, Duque enseña que las circunstancias inclinan al pecado: en el trabajo el corazón sé pone bravo, otras veces el mayoral apremia en exceso, mi propio corazón incita al pecado, veo que otros me insisten o apuran para que haga el mal. Ante semejante panorama, ¿cómo aguantar? Duque enseña que muchos lo han conseguido: son los santos. Y es preciso tener la seguridad de que Dios ayuda; en consecuencia, convendrá repetir esto al hablar de servir a Dios, al recordar la utilidad del padrenuestro, o insistir en la asistencia a la misa ${ }^{94}$.

91. Este concepto estaba ya presente en las páginas 95 y 103.

92. Utiliza una comparación: «¿Por qué nacieron ustedes negros? Porque son hijos de negros; ustedes no tuvieron culpa de nacer negros, pero más que no tengan culpa nacieron negros» (Pg. 113). Puede ser muy coloquial, pero asociar el concepto de "culpa" con el concepto de "negro", y no con el de "blanco", parece dejar caer una especie de baldón adicional a su ya infamante condición de esclavos.

93. Ya ha aparecido la frase de que «Dios era el amo», y por tanto, nosotros sus esclavos; también había afirmado Duque que «la Virgen era el ama». Ahora aparece otra frase como es la de «ser esclavos del diablo». EI lenguaje equívoco podía crear no poca desorientación entre los esclavos.

94. En este tratado sobre el bautismo, hay nada menos que seis llamadas o referencias internas que Duque realiza a otros lugares de su escrito, remitiendo a las materias que ya ha explicado. Esto muestra sin dudas que Duque escribió con un orden no demasiado riguroso, pero que su idea estaba bien clara, de forma que trata de presentar aquello que es útil para educar en la fe, aunque la falta de orden haga del suyo un escrito no demasiado pedagógico. 
F) Sobre la eucaristía. Tanto este penúltimo tratado, como el que sigue, están dirigidos a los esclavos, con su estilo característico. El que se ocupa de la eucaristía recuerda a los destinatarios lo ya enseñado de la concepción de los sacramentos como remedios, como boticas. El alma, después de recuperada por la penitencia queda sana, pero débil. Precisamente para esto Jesús hizo este sacramento, para que, comiéndolo los cristianos, tuvieran el alma muy fuerte. Cuando luchan dos personas, pierde el más débil; y nosotros tenemos que aguantar las embestidas de nuestros enemigos ( Diablo, gente mala y nuestro mismo cuerpo»). El cuerpo de Cristo nos hace fuertes para que no pequemos y nuestros enemigos no nos puedan derribar.

G) Sobre los mandamientos. Ya había hablado del tema, tanto en el Catecismo, como en la Explicación; ello no le impide volver a hacerlo con relativa extensión en este último "tratado", y en unos cuantos puntos con no poco acierto.

Comienza con la afirmación - que hasta ahora no había aparecido, porque ha omitido todos los formularios catequéticos habituales- de que los mandamientos son diez; es decir, no demasiados; unos se refieren a Dios, y otros al prójimo95. Explica la noción de amar, como equivalente a querer mucho, y lo aplica a los mandamientos. Dios manda que se le ame con un amor total:

«más que al padre, más que a la madre, más que al hijo, más que a la muger, más que al marido, más que al cuerpo, más que a la vida, más que al alma, más que al dinero, más que a su casa, más que a los parientes, más que a sus compañeros, más que a sus amos, más que a sus calaberas, y más que a todas las cosas; ninguna cosa se ha de querer más que a Dios; a Dios es preciso quererlo siempre más que a todas las cosas»96.

Cuando pasa a hablar del amor al prójimo, lo primero que afirma es que todos quieren que no les maldigan, ni les falten al respeto, ni les insulten. Esto es lo que manda Dios, que lo que no quiero para mí no lo quiera para otro.

95. Al señalar que todos somos prójimos, sin excepciones, Duque enuncia una larga lista, extremadamente interesante, en la que hace desfilar a casi todos los tipos de personas que constituían la sociedad del momento. «Próximos son toda la gente: hombre, muger, muchacho, viejo, mulato, indio, blanco, amo, esclavo, libre, negro, criollo, bozal, de qualquier casta -carabalí, congo, mina, mandinga, lucumí, ganga, chambá, malagás- grande, chico, rico, pobre, que tiene enfermo (=enfermedad), que no tiene enfermo, que son bueno, que son malo, que tienen buen corazón, que tienen mal corazón» (Pg. 116).

96. Pg. 116. Los "calaberas" (también aparece como "calaveras", o "carabela") equivale a compañero, compadre. 
Apoyando el argumento con la experiencia de los destinatarios, todos se alegran cuando alguien les presta dinero o les ayuda estando enfermos.

Sin embargo surge una grave dificultad para la práctica del amor como Dios lo desea: hay gente que hace el mal a los demás; ¿cómo querer a los que me hacen el mal? Es el difícil tema del perdón y del amor a los enemigos, que en cierto modo encrespa la lógica de la conducta humana. Duque presenta la respuesta típicamente cristiana en dos registros: por una parte, hacer esto es lo que Dios quiere y manda, y él es el amo; por otra parte, quien no lo hace así, no cumple con su obligación, y Dios lo castigará. Esto le lleva a presentar como rechazable la venganza, pues Dios no quiere que se porten así los buenos cristianos.

Más aún, el capellán se ha de presentar a los esclavos como quien les quiere, como quien les acepta como los hijos que Dios le dio, de forma que nadie pueda decir «el padre no me quiere»; la consecuencia es que no les dice cosas malas, y les pide que sigan su consejo sobre el perdón y la eliminación de la venganza.

El otro argumento que emplea Duque es que la venganza no es propia de cristianos, y ellos ahora lo son; no es lo mismo que cuando no le conocían porque estaban en Guinea, y no habían tenido oportunidad de que nadie les hablara de Dios. La venganza no es cosa de cristianos, sino de paganos:

«No tengan corazón duro, no fagan como gente que está en Guinea, que no conoce a Dios, ni sabe cosa que Dios manda. Ya Guinea se acabó, ya ustedes nunca volverán allá, ya son christianos, ya son hijos de Dios, ya saben los mandamientos de la ley de Dios, ya saben que los que guardan esos mandamientos van al cielo; y los que no los guardan van al infierno»97.

Aún añade otra razón de índole religiosa: todos son pecadores, y por tanto todos necesitados del perdón de Dios. Él dice: perdona y te perdonaré; el perdón de Dios está condicionado al perdón que los hombres seamos capaces de otorgar a nuestros prójimos.

97. Pg. 119. En las palabras reproducidas no hay un fatalismo de Duque con respecto a la suerte de los esclavos, sino el reconocimiento del hecho de que no es posible el retorno. Y que en la nueva situación en la que se encuentran -a su pesar- han tenido la ocasión de hacerse cristianos y conocer la doctrina de Jesús, que supera la venganza con el amor a los enemigos. Duque invita a los esclavos a que se porten en consonancia con la situación en que se encuentran ahora. El contraste con la situación anterior no es para despreciar aquélla ni para ensalzar ésta. 
Además de las razones religiosas, Duque de Estrada recomienda que en caso de agresiones entre esclavos acudan al mayoral o al amo en espera de justicia; y -aquí sí que hay que hablar de ingenuidad por parte de Duquecaso de no ser atendidos, acudan al gobernador o al alcalde para que establezcan la justicia vulnerada. Difícilmente se puede pensar que el gobernador se prestara a actuar como juez en un conflicto entre esclavos por los daños que uno causara a otro.

H) [Recomendación final a los capellanes]. Sin título alguno que diferencie el párrafo final -al que me voy a referir ahora- de cuanto le precede, Duque termina este amplio apartado sobre los mandamientos. En el último párrafo, que podría titularse Recomendación final a los capellanes, Antonio Nicolás Duque de Estrada hace las últimas advertencias, alguna de las cuales es reiterativa mirando al resto del escrito. Tales recomendaciones se resumen en las siguientes:

- Duque ha puesto a disposición de otros capellanes cuanto le ha parecido provechoso para que cumplan con su deber: ganar el cielo y ser útiles a los demás, donde sólo pueden serlo ellos.

- Lo presentado y escrito no servirá de nada si no está acompañado de la constancia.

- Siempre que tengan oportunidad, aprovéchenla para llevar a cabo la instrucción religiosa.

- Que se esfuercen por que los esclavos tengan preocupación por aprender; y que vean en los capellanes preocupación por enseñar.

- Que no hay exhortación más eficaz que el dar ejemplo

- Que el no cumplir con el propio deber, o disculparse, genera hábito de pereza y de falta de interés.

Por último ruega que tengan misericordia de los negros, con el íntimo convencimiento, expresado en el escrito, de que muchos de los esclavos se condenarán por falta de instrucción. Este pensamiento de Duque está acorde con la mentalidad que había manifestado de presentar las verdades necesarias con necesidad de medio para la salvación, y que su desconocimiento, culpable o no, implica la condenación. Para Duque prima este criterio rígido, y no es capaz de examinarlo con una mentalidad que contemple la importancia de las objetivas circunstancias atenuantes que impedían a los negros semejante conocimiento cristiano en plenitud. Su situación era bien distinta de quienes pudiendo acceder a un conocimiento cristiano asequible e inteligible, despreciaban expresamente la enseñanza de la fe. 


\section{EXAMEN DE DOS CUESTIONES EN PARTICULAR}

Ya he mostrado mi desacuerdo con Laviña en numerosas cuestiones relativas al fondo y a la forma con que él contempla el Catecismo escrito por Antonio Nicolás Duque. Su enfoque economicista discrepa muy seriamente de mi consideración catequética; y su mentalidad marxista también diverge de mi convencimiento creyente. A riesgo de ser reiterativo, quiero examinar dos cuestiones en particular, relacionadas entre sí, y con las cuales Laviña cierra su intervención en la obra. He aquí sus palabras:

«Es evidente que la primera y principal función que debía cubrir [la religión] era la adaptación del esclavo al sistema de plantación, de ahí el interés del capellán en establecer comparaciones entre Dios y el amo, o entre el paraíso y la casa de purga (...) Si Duque de Estrada, aparentemente un clérigo de buena voluntad, establece las curiosas comparaciones que he apuntado en las páginas anteriores, no es de extrañar que ante la posibilidad de un cielo gobernado por un "Padre-mayoral", o un "Padre-amo" el esclavo optase por un infierno, aunque no pudiera moverse ni para rascarse la cabeza» 98 .

Me parece oportuno examinar con más pormenor lo que Duque dice sobre Dios; así como lo que enseña sobre el cielo y el infierno.

Sobre Dios, es cierto que establece la comparación con el amo. No seré yo quien lo niegue. Pero, ¿se trata de "interés" de Duque, o se trata de adaptación catequética por referirse a la máxima autoridad que los esclavos podían conocer en su estrecho mundo?

Como es malo dejarse llevar por las interpretaciones personales, es preferible empezar por reproducir las expresiones literales de Duque de Estrada con relación a Dios:

«También es preciso que sepan ustedes que todas estas cosas que Dios crió no le costaron trabajo: sólo querer. Dios quiere una cosa? Él manda, y lo que él manda se face aprisa, aprisa; ni pasa tiempo ni cuesta trabajo, y a esto se llama ser todopoderoso (...) Sólo Dios es todopoderoso. (Aquí vendrá bien el símil de lo que cuesta a sus amos hacer azúcar, los gastos que tienen, los hombres y los animales que necesitan para hacerla, de que se puede hacer detalle)»99.

98. Pg. 125.

99. Pg. 78-79. 
«Así desde que nacemos, desde que nos parió nuestra madre somos esclavos de Dios, porque él es el amo de todo, y tenemos obligación de servirle, como el esclavo a su amo: lo que Dios quiere que hagamos es que guardemos sus mandamientos, que no fagamos pecado. Esa es nuestra tarea. Llega el día del juicio, día en que se acaba todo el mundo; ése es como el sábado o como el lunes por la mañana; entonces vendrá nuestro señor Jesucristo desde el cielo a tomar cuenta, a ver si hemos fecho nuestra tarea, si hemos guardado sus mandamientos, si hemos fecho pecado, y al que no ha cumplido su obligación lo castiga, como castiga el mayoral al que no cumple su tarea.

Pero miren ustedes cómo Dios no face como mayoral, ni como amo, sino como padre. Acá, quando el esclavo cumplió su tarea no lo castigan, pero tampoco le pagan nada (...) Pero Dios no face así: al que cumple su tarea, al que guarda sus mandamientos, no se calla Dios la boca, sino que le dice: ven acá, fulano; tú has cumplido con tu obligación, no como mal esclavo, sino como buen hijo; ven aora al cielo para estar siempre conmigo que soi tu Dios, y tu Señor y tu Padre a descansar para siempre, para siempre» ${ }^{100}$.

«Díganme ustedes: un esclavo no ha de tener cortesía con su amo? Un hijo no ha de tener cortesía con su padre? Si, señor, es preciso tener cortesía. El esclavo que no tiene cortesía con su amo es mal esclavo; el hijo que no tiene cortesía con su padre es mal hijo. Todos los christianos saben que Dios es nuestro amo, nuestro Señor, a quien es preciso servir. Todos saben que Dios es nuestro Padre, y por eso le decimos Padre nuestro que estás en los cielos; con que es preciso tener cortesía con Dios como buenos hijos, pues con la misa es con lo que damos a Dios la cortesía que le debemos, como a Padre, y como a Señor y amo de todos nosotros, y eso es lo que se llama honrar a Dios»101.

«¿Cómo yo quiero mucho gente que me face malo a mí? ¿Cómo? Porque Dios quiere, porque Dios manda que le faga bueno a su próximo, mas que su próximo le faga malo a él. No es menester más. Dios es el amo, él lo manda, es preciso facer lo que Dios manda. (...) Los christianos buenos, más que el otro les face malo a él, él no face malo al otro; si él puede le face bueno, porque sabe que eso es lo que le gusta a Dios, eso es lo que Dios quiere, lo que Dios manda; a esos les perdonará Dios sus pecados, les dará buena muerte y les llevará al cielo; pero los que no facen lo que Dios quiere, lo que Dios le manda, ése tendrá mala muerte, y irá al infierno para siempre»102.

100. Pg. 88-89.

101. Pg. 107.

102. Pg. 118. 
Me era indispensable incluir citas un tanto largas, para no extraer alguna frase aislada del contexto inmediato, y para que se viera en verdad el pensamiento de Duque de Estrada. Es rigurosamente cierto que compara a Dios con el amo, la máxima autoridad que el esclavo podía contemplar. Pero con el mismo rigor hay que afirmar que Duque establece las diferencias entre Dios y el amo; diferencias que quedan clarísimas, incluso para los esclavos con el escaso nivel de comprensión de la lengua.

Por otra parte la referencia a Dios como Padre aparece meridiana: es un padre que quiere a los suyos, que les manifiesta su voluntad y que espera de su conducta que cumplan su voluntad. El amor de hijos para con su padre, al que Duque invita a los esclavos, acorde con las enseñanzas del evangelio, aparece en las frases reproducidas con la misma evidencia con que aparece la expresión de que Dios es el amo. No es posible fijarse en una y no poner atención en la otra. Y proceder de otra manera es simple y vulgar manipulación.

Además, en ningún momento aparece la imagen de un Dios colérico, vengativo, o sediente de sangre y castigo. Lo que aparece de las mismas expresiones de Duque es la imagen de un Dios que expresa cuál es su voluntad, y espera de sus hijos que la cumplan. Pero que con lealtad y sin engaños, advierte por adelantado la posibilidad de premio o castigo, dejando al hombre que escoja conscientemente, sabedor de su suerte.

En consecuencia, llegar a la conclusión, expresada por Laviña, de que Dios es un "Padre-mayoral", o un "Padre-amo", al que se teme, y del que se huye, es falsificar las expresiones de Antonio Nicolás Duque.

Vamos con la segunda cuestión, conectada con la anterior. Si de ese Dios, falsamente diseñado por Laviña, lo mejor que se puede hacer es huir y alejarse, la consecuencia que también extrae es que resulta preferible eludir el cielo y que «el esclavo optase por el infierno, aunque no pudiera moverse ni para rascarse la cabeza». En las palabras de Laviña, entrecomilladas, hay una mordaz ironía, como si con ellas, como remate del epílogo, colocara el rejón de muerte a la bienintencionada obra de Duque.

Es preciso, de nuevo, acudir a las palabras de Duque, reproducidas tal cual:

«P. ¿Con que el cielo no se acaba nunca ni el infierno tampoco se acaba? R. No, señor, nunca, nunca se acaba ni el infierno ni el cielo; eso se llama para siempre, que no se acaba nunca; que el que va al cielo siempre estará contento de estar con Dios, mirándolo siempre, sin cansarse nunca de mirarlo; y mientras más lo mira, más ganas tiene de mirarlo, porque él querrá muchísimo a Dios, y conocerá que Dios lo quiere muchísimo a él, más que su padre o su madre. Que 
el que va por sus pecados al infierno, siempre, siempre estará pasando trabajos, pero esos trabajos no son como trabajo que pasa aquí; son trabajos que nadie puede pensar, trabajos mui grandes; siempre quemándose, siempre llorando, porque él sabe que ya no puede nunca, nunca, mirar a Dios, y que Dios estará siempre bravo con él, y que nadie puede ser su padrino para que Dios le perdone»103.

«Salvarse es ir al cielo a ver a Dios, a estar con Dios, a vivir en la misma casa de Dios, no en la cocina, sino en la sala, a comer en la misma mesa de Dios con la virgen santísima, que es nuestra madre, con los ángeles, con los santos, que son nuestros hermanos. Salvarse es no caer en el infierno, donde se pasan trabajos que nadie puede pensar, y que nunca se acaban. Salvarse es ir a descansar para siempre al cielo donde no hai frío ni calor, ni fambre, ni sed, ni sueño, ni trabajo, ni castigo, ni esclavo, ni amo, ni enfermo ninguno, ni pesadumbre, ni miedo, ni muerte, ni pecado. Salvarse es ir a vivir siempre en el cielo, donde no hai otra cabeza que Dios, donde ninguno tiene mal corazón para otro, donde todos se quieren muchísimo, y ninguno se pone bravo, ninguno pelea, ninguno deshonra a otro, ninguno dice: esto es mío, esto es tuyo, porque todo es de todos, a ninguno le falta nada. Esto, ¿no es cosa muy buena? ¿No les da ganas de ir al cielo? Pues todo esto que yo he dicho es poquito: Cielo es cosa más bueno que todo esto; ninguna gente, mas que sabe mucho, puede fablar cosa que hai en el cielo; mas que fabla cosa que nadie puede pensar. Cielo es mejor»104.

«Los infiernos son quatro calabozos que están debajo de la tierra, en medio, en medio. Mas en medio, en medio, debajo de todos está el infierno donde están los diablos y las almas de los que mueren con pecado mortal. Este calabozo es mui grande, porque en él han de caber todos los cuerpos de los que mueren con pecado mortal, porque el día del juicio se han de volver a juntar con sus almas, y así, vivos, cuerpo y alma juntos, estarán en el infierno. Y como Dios sabe cuántos son los que se han de morir con pecado mortal, por eso fizo este calabozo tan grande, para que quepan todos, sin que ninguno se escape; pero aunque cabrán todos, estarán tan apretados que no podrán menearse, ni rascarse la cabeza. Este calabozo está lleno de candela, como forno de fundición o como forno de teja, y allí se están quemando y se quemarán para siempre, siempre, los diablos y los que mueren con pecado mortal, sin que se puedan morir, porque los cuerpos después que se vuelven a juntar con sus almas, no se mueren nunca más, nunca, y así se quemarán en el infierno, no como se quema la leña,

103. Pg. 90.

104. Pg. 102. 
que se face seniza, y se acaba, sino como ladrillo, que está encendido y no se face seniza»105.

Aun contando con las muchas referencias materiales en los textos reproducidos (¿cómo hablar del cielo o del infierno adecuadamente?; ¿cómo a los esclavos de Cuba?), ¿es posible deducir de las expresiones de Duque que es preferible ir al infierno, aunque apretujados, lejos de un Dios tirano (que no aparece en el escrito)? ¿Por qué Laviña se fija en el detalle de estar apretujados, sin poderse rascar, y no se fija en la descripción del cielo como la felicidad de estar junto a Dios, amarle y saberse amado por Él? ¿No es esto manipulación? ¿No es lectura segada, interesadamente sesgada? Los textos, todos los textos, estaban al alcance de Laviña, responsable de la transcripción. Pero se ha fijado en unos y ha olvidado otros. Una dosis del elemental respeto con la obra ajena, para evitar tergiversarla, no hubiera estado de más.

Ni Dios aparece como un ogro, o como un tiranuelo voluble; ni el cielo aparece como una desgraciada situación de la que hay que salir huyendo, precisamente por la presencia de ese imaginado torturador; ni el infierno aparece como la mejor situación, apetecible, lejos del Dios sanguinario y cruel, copia agigantada del amo o del mayoral. Y decir -o insinuar- lo contrario, e ironizar sobre ello, con la conciencia de haber hecho un gran descubrimiento, no es más que falsificar los textos.

LUIS RESINES

Estudio Teológico Agustiniano

Valladolid

105. Pg. 86. 